\title{
Nitrile ligands activation in dinuclear aminocarbyne complexes
}

\author{
Luigi Busetto, Fabio Marchetti, Stefano Zacchini, Valerio Zanotti * and Eleonora Zoli
}

Dipartimento di Chimica Fisica ed Inorganica, Università di Bologna, Viale Risorgimento 4, I40136 Bologna, Italy

\begin{abstract}
The

diiron

complexes

$\left[\mathrm{Fe}(\mathrm{Cp})(\mathrm{CO})\left\{\mu-\eta^{2}: \eta^{2}-\right.\right.$ $\left.\left.\mathrm{C}[\mathrm{N}(\mathrm{Me})(\mathrm{R})] \mathrm{N}=\mathrm{C}\left(\mathrm{C}_{6} \mathrm{H}_{3} \mathrm{R}^{\prime}\right) \mathrm{C}=\mathrm{CH}(\mathrm{Tol})\right\} \mathrm{Fe}(\mathrm{Cp})(\mathrm{CO})\right]\left(\mathrm{R}=\mathrm{Xyl}, \mathrm{R}^{\prime}=\mathrm{H}, \mathbf{3 a} ; \mathrm{R}=\mathrm{Xyl}, \mathrm{R}^{\prime}=\mathrm{Br}, \mathbf{3 b} ; \mathrm{R}\right.$ $=\mathrm{Xyl}, \mathrm{R}^{\prime}=\mathrm{OMe}, \mathbf{3 c} ; \mathrm{R}=\mathrm{Xyl}, \mathrm{R}^{\prime}=\mathrm{CO}_{2} \mathrm{Me}, \mathbf{3 d} ; \mathrm{R}=\mathrm{Xyl}, \mathrm{R}^{\prime}=\mathrm{CF}_{3}, \mathbf{3 e} ; \mathrm{R}=\mathrm{Me}, \mathrm{R}^{\prime}=\mathrm{H}, \mathbf{3 f} ; \mathrm{R}=$ $\left.\mathrm{Me}, \mathrm{R}^{\prime}=\mathrm{CF}_{3}, \mathbf{3 g}\right)$ are obtained in good yields from the reaction of $\left[\mathrm{Fe}_{2}\{\mu-\mathrm{CN}(\mathrm{Me})(\mathrm{R})\}(\mu-\right.$ $\left.\mathrm{CO})(\mathrm{CO})\left(\mathrm{p}-\mathrm{NCC}_{6} \mathrm{H}_{4} \mathrm{R}^{\prime}\right)(\mathrm{Cp})_{2}\right]^{+}\left(\mathrm{R}=\mathrm{Xyl}, \mathrm{R}^{\prime}=\mathrm{H}, \mathbf{2} \mathbf{a} ; \mathrm{R}=\mathrm{Xyl}, \mathrm{R}^{\prime}=\mathrm{Br}, \mathbf{2 b} ; \mathrm{R}=\mathrm{Xyl}, \mathrm{R}^{\prime}=\mathrm{OMe}\right.$, 2c; R = Xyl, R' = $\mathrm{CO}_{2} \mathrm{Me}, \mathbf{2 d} ; \mathrm{R}=\mathrm{Xyl}, \mathrm{R}^{\prime}=\mathrm{CF}_{3}, \mathbf{2 e} ; \mathrm{R}=\mathrm{Me}, \mathrm{R}^{\prime}=\mathrm{H}, 2 \mathrm{f} ; \mathrm{R}=\mathrm{Me}, \mathrm{R}^{\prime}=\mathrm{CF}_{3}, \mathbf{2 g}$ ) with TolC $\equiv \mathrm{CLi}$. The formation of $\mathbf{3}$ involves addition of the acetylide at the coordinated nitrile and $\mathrm{C}-\mathrm{N}$ coupling with the bridging aminocarbyne together with orthometallation of the $p$-substituted aromatic ring and breaking of the Fe-Fe bond. Complexes 3a-e which contain the N(Me)(Xyl) group exist in solution as mixtures of the E-trans and Z-trans isomers, whereas the compounds $\mathbf{3 f}, \mathbf{g}$, which posses an exocyclic $\mathrm{NMe}_{2}$ group, exist only in the $Z$-cis form. The crystal structures of $Z$ trans-3b, E-trans-3c, Z-trans-3e and Z-cis-3g have been determined by X-ray diffraction experiments.
\end{abstract}

Keywords: nitrile, acetylide addition, aminocarbyne, diiron complexes, crystal structure Corresponding author e-mail address: valerio.zanotti@unibo.it

\section{Introduction}

Activation of nitriles by coordination to transition metals is a very important issue in organometallic chemistry and plays a fundamental role in organic synthesis [1]. Depending on the nature of the organometallic frame, coordinated nitriles can react with both nucleophiles and electrophiles or display increased $\alpha-\mathrm{CH}$ acidity [2]. Activation towards nucleophilic addition can result in enhancement of the reaction rate from $10^{6}$ to $10^{10}$ and occasionally to $10^{18}$ [3]. Nucleophilic additions to metal coordinated nitriles mostly involve protic nucleophiles such as 
amines [4], alcohols [5] and water [6], leading to the formation of the corresponding amidines, imidoesters and amidates. Additions of carbon nucleophiles are also known, although less common [7].

We have recently investigated the reactivity of diiron and diruthenium aminocarbyne complexes containing nitriles, i.e. $\left[\mathrm{M}_{2}\{\mu-\mathrm{CN}(\mathrm{Me})(\mathrm{R})\}(\mu-\mathrm{CO})(\mathrm{CO})\left(\mathrm{NCCR}{ }^{\prime}\right)(\mathrm{Cp})_{2}\right]^{+}(\mathrm{M}=\mathrm{Fe}, \mathrm{Ru} ; \mathrm{R}$ $\left.=\mathrm{Xyl}, \mathrm{Bz}, \mathrm{Me} ; \mathrm{R}^{\prime}=\mathrm{Me}, \mathrm{CMe}_{3}\right)$. Although acetonitrile is readily displaced, in the above complexes, by a variety of ligands including amines, imines, phosphines, isocyanides, cyanide, hydride and halides, [8] it has been found that treatment with $\mathrm{NaH}$ or LiR removes a proton from the coordinated $\mathrm{MeCN}$, and consequently promotes its rearrangement to cyanomethyl ligand [9].

Dinuclear complexes containing trimethylacetonitrile, $\quad\left[\mathrm{M}_{2}\{\mu-\mathrm{CN}(\mathrm{Me})(\mathrm{R})\}(\mu-\right.$ $\left.\mathrm{CO})(\mathrm{CO})\left(\mathrm{NCCCMe}_{3}\right)(\mathrm{Cp})_{2}\right]^{+}[\mathrm{M}=\mathrm{Fe}, \mathrm{Ru} ; \mathrm{R}=\mathrm{Xyl}, \mathrm{Me}]$, lack of acidic $\alpha-\mathrm{CH}$. Their reactions with acetylides proceed via LiCCR' addition to the nitrile affording, after protonation, the alkynyl imino complexes $\left[\mathrm{M}_{2}\{\mu-\mathrm{CN}(\mathrm{Me})(\mathrm{R})\}(\mu-\mathrm{CO})(\mathrm{CO})\left\{\mathrm{N}(\mathrm{H})=\mathrm{C}\left(\mathrm{CMe}_{3}\right)\left(\mathrm{C}_{\left.\equiv \mathrm{CR}^{\prime}\right)}\right)(\mathrm{Cp})_{2}\right]^{+}[8 \mathrm{~b}, 10]\right.$. In the case of the diiron complexes, the reaction can further proceed via coupling between the azavinylidene intermediate and the bridging aminocarbyne resulting, upon addition of $\mathrm{CF}_{3} \mathrm{SO}_{3} \mathrm{H}$, in the formation of the $\mu$-allenyl-diaminocarbene complex $\left[\mathrm{Fe}_{2}\left\{\mu-\eta^{1}: \eta^{3}-\mathrm{C}(\mathrm{Tol})=\mathrm{C}=\mathrm{C}\left(\mathrm{CMe}_{3}\right) \mathrm{N}(\mathrm{H}) \mathrm{CN}(\mathrm{Me})(\mathrm{Xyl})\right\}(\mu-\right.$ $\left.\mathrm{CO})(\mathrm{CO})\left(\mathrm{Cp}_{2}\right)\right]^{+}[10]$. The latter reaction represents an interesting example in which the diiron aminocarbyne frame acts as a template for the preparation of new ligands via formation of new C-C and $\mathrm{C}-\mathrm{N}$ bonds.

With the aim of extending our knowledge on the activation of nitriles by dinuclear aminocarbyne complexes, we have investigated the reactions of diiron aminocarbyne complexes containing aryl nitriles, with $\mathrm{TolC} \equiv \mathrm{CLi}$. The results of these studies are the object of this paper.

\section{Results and Discussion}

The nitrile complexes $\left[\mathrm{Fe}_{2}\{\mu-\mathrm{CN}(\mathrm{Me})(\mathrm{R})\}(\mu-\mathrm{CO})(\mathrm{CO})\left(\mathrm{p}-\mathrm{NCC}_{6} \mathrm{H}_{4} \mathrm{R}^{\prime}\right)(\mathrm{Cp})_{2}\right]^{+}(\mathrm{R}=2,6-$ $\mathrm{Me}_{2} \mathrm{C}_{6} \mathrm{H}_{3}(\mathrm{Xyl}), \mathrm{R}^{\prime}=\mathrm{H}, \mathbf{2} \mathbf{a} ; \mathrm{R}=\mathrm{Xyl}, \mathrm{R}^{\prime}=\mathrm{Br}, \mathbf{2 b} ; \mathrm{R}=\mathrm{Xyl}, \mathrm{R}^{\prime}=\mathrm{OMe}, \mathbf{2} \mathbf{c} ; \mathrm{R}=\mathrm{Xyl}, \mathrm{R}^{\prime}=\mathrm{CO}_{2} \mathrm{Me}$, 2d; R = Xyl, R' = $\mathrm{CF}_{3}, \mathbf{2 e} ; \mathrm{R}=\mathrm{Me}, \mathrm{R}^{\prime}=\mathrm{H}, \mathbf{2 f} ; \mathrm{R}=\mathrm{Me}, \mathrm{R}^{\prime}=\mathrm{CF}_{3}, \mathbf{2 g}$ ) can be obtained in high yield by $\mathrm{Me}_{3} \mathrm{NO}$ assisted replacement of a $\mathrm{CO}$ ligand of $\left[\mathrm{Fe}_{2}\{\mu-\mathrm{CN}(\mathrm{Me})(\mathrm{R})\}(\mu-\right.$ $\left.\mathrm{CO})(\mathrm{CO})_{2}(\mathrm{Cp})_{2}\right]\left[\mathrm{SO}_{3} \mathrm{CF}_{3}\right](\mathrm{R}=\mathrm{Xyl}, \mathbf{1 a} ; \mathrm{Me}, \mathbf{1 b})$ in THF (Scheme 1), following the same procedure previously reported for the analogous acetonitrile and trimethylacetonitrile complexes [8a]. Complexes $\mathbf{2}$ have been fully characterised by spectroscopic methods (NMR and IR) and elemental analyses (see Experimental). 
Scheme 1

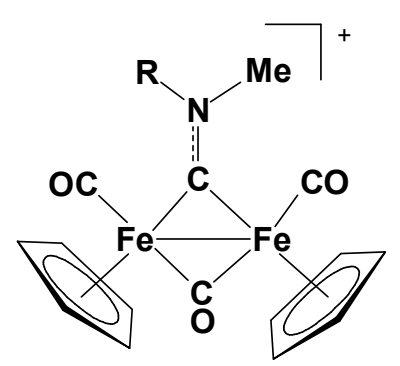

1)

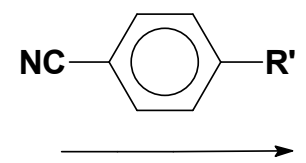

2) $\mathrm{Me}_{3} \mathrm{NO}$ in THF

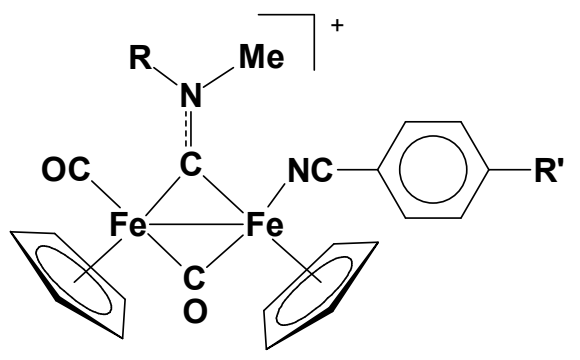

$$
\begin{aligned}
& R=X y \mid \mathbf{1 a} \\
& R=\operatorname{Me} \mathbf{1 b}
\end{aligned}
$$

$\begin{array}{lll} & \text { R } & \mathbf{R}^{\prime} \\ \mathbf{2 a} & \mathrm{Xyl} & \mathrm{H} \\ \mathbf{2 b} & \mathrm{Xyl} & \mathrm{Br} \\ \mathbf{2 c} & \mathrm{Xyl} & \mathrm{OMe} \\ \mathbf{2 d} & \mathrm{Xyl} & \mathrm{COOMe} \\ \mathbf{2 e} & \mathrm{Xyl} & \mathrm{CF}_{3} \\ \mathbf{2 f} & \mathrm{Me} & \mathrm{H} \\ \mathbf{2 g} & \mathrm{Me} & \mathrm{CF}_{3}\end{array}$

The reaction of 2 with TolC $\equiv \mathrm{CLi}\left(\mathrm{Tol}=p-\mathrm{MeC}_{6} \mathrm{H}_{4}\right)$ in THF at low temperature, followed by stirring at room temperature for one hour affords the new diiron complexes $\left[\mathrm{Fe}(\mathrm{Cp})(\mathrm{CO})\left\{\mu-\eta^{2}: \eta^{2}-\right.\right.$ $\left.\left.\mathrm{C}[\mathrm{N}(\mathrm{Me})(\mathrm{R})] \mathrm{N}=\mathrm{C}\left(\mathrm{C}_{6} \mathrm{H}_{3} \mathrm{R}^{\prime}\right) \mathrm{C}=\mathrm{CH}(\mathrm{Tol})\right\} \mathrm{Fe}(\mathrm{Cp})(\mathrm{CO})\right]\left(\mathrm{R}=\mathrm{Xyl}, \mathrm{R}^{\prime}=\mathrm{H}, \mathbf{3 a} ; \mathrm{R}=\mathrm{Xyl}, \mathrm{R}^{\prime}=\mathrm{Br}, \mathbf{3 b} ; \mathrm{R}\right.$ $=\mathrm{Xyl}, \mathrm{R}^{\prime}=\mathrm{OMe}, \mathbf{3 c} ; \mathrm{R}=\mathrm{Xyl}, \mathrm{R}^{\prime}=\mathrm{CO}_{2} \mathrm{Me}, \mathbf{3 d} ; \mathrm{R}=\mathrm{Xyl}, \mathrm{R}^{\prime}=\mathrm{CF}_{3}, \mathbf{3 e} ; \mathrm{R}=\mathrm{Me}, \mathrm{R}^{\prime}=\mathrm{H}, \mathbf{3 f} ; \mathrm{R}=$ $\mathrm{Me}, \mathrm{R}^{\prime}=\mathrm{CF}_{3}, \mathbf{3 g}$ ), which are obtained in good yields (ca. $60 \%$ ) after column chromatography (Scheme 2).

\section{Scheme 2}

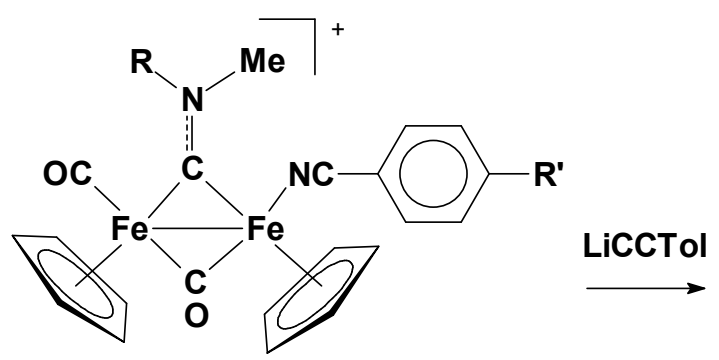

2a-g

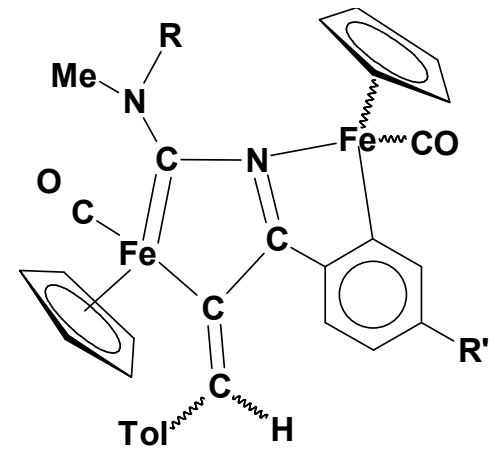

$\begin{array}{lll} & \mathbf{R} & \mathbf{R}^{\prime} \\ \mathbf{3 a} & \mathrm{Xyl} & \mathrm{H} \\ \mathbf{3 b} & \mathrm{Xyl} & \mathrm{Br} \\ \mathbf{3 c} & \mathrm{Xyl} & \mathrm{OMe} \\ \mathbf{3 d} & \mathrm{Xyl} & \mathrm{COOMe} \\ \mathbf{3 e} & \mathrm{Xyl} & \mathrm{CF}_{3} \\ \mathbf{3 f} & \mathrm{Me} & \mathrm{H} \\ \mathbf{3 g} & \mathrm{Me} & \mathrm{CF}_{3}\end{array}$


The crystal structures of $\mathbf{3 b}, \mathbf{3 c}, \mathbf{3 e}$ and $\mathbf{3 g}$ have been determined by X-ray diffraction studies. Their molecular structures are shown in Figures 1-4, whereas the most relevant bond lengths and bond angles are reported in Tables 1 and 2.

\section{Figure 1}

Molecular structure of $\mathbf{3 b}$ (all $\mathrm{H}$ atoms, apart from H16, have been omitted). Displacement ellipsoids are at $30 \%$ probability level.

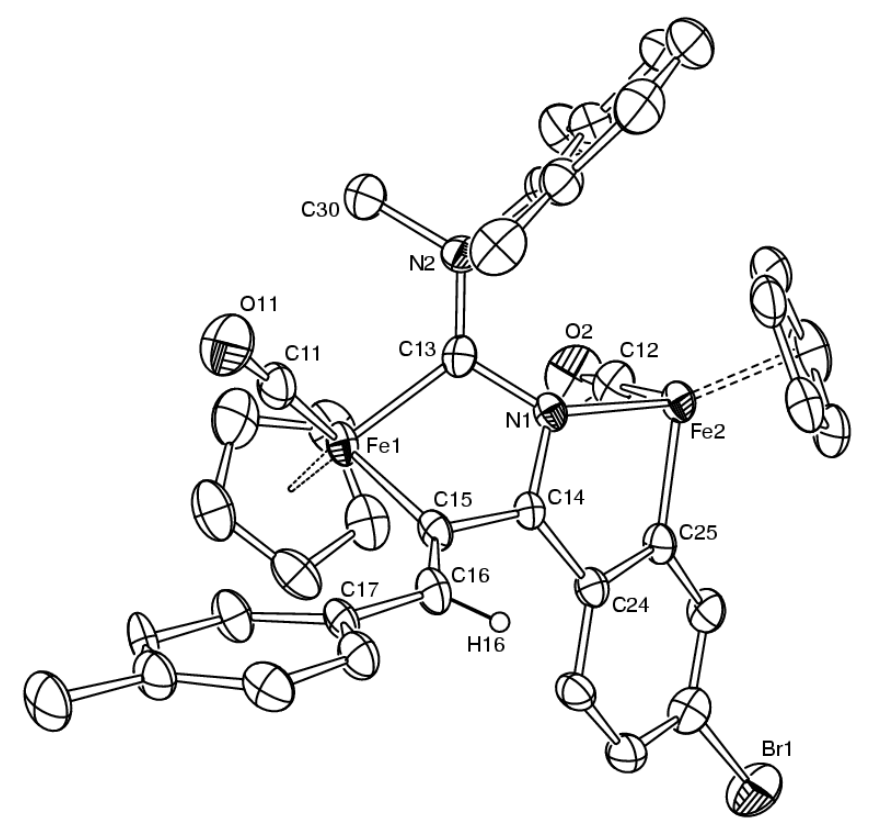

Figure 2

Molecular structure of 3c (all H atoms, apart from H16, have been omitted). Only one of the two independent molecules is represented. Displacement ellipsoids are at 30\% probability level. 


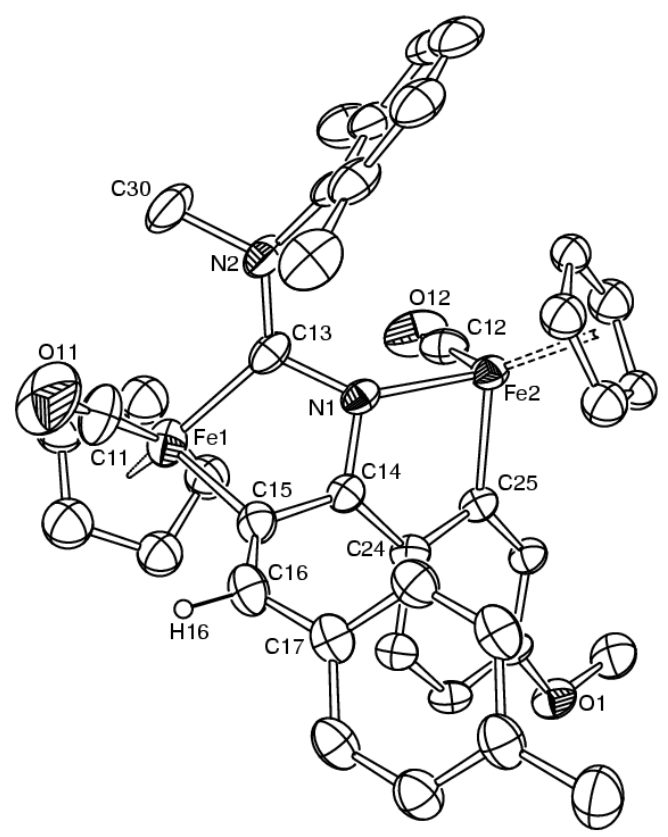

Figure 3

Molecular structure of 3e (all H atoms, apart from H16, have been omitted). Displacement ellipsoids are at $30 \%$ probability level.

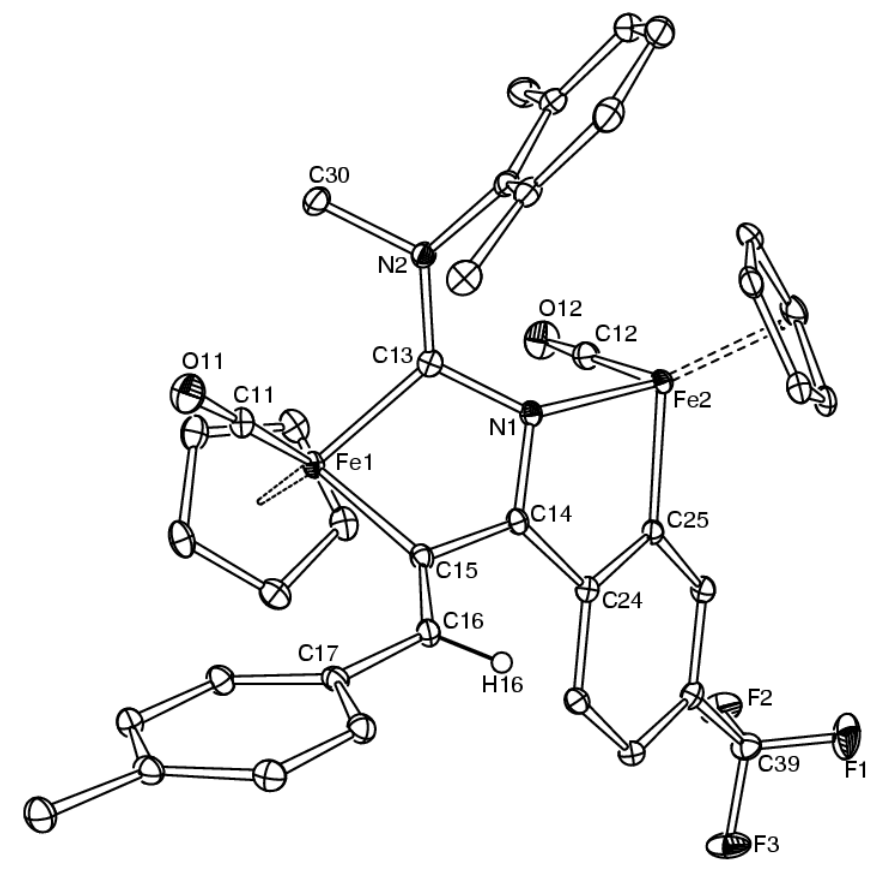

Figure 4

Molecular structure of $\mathbf{3 g}$ (all $\mathrm{H}$ atoms, apart from H16, have been omitted). Displacement ellipsoids are at $30 \%$ probability level. 


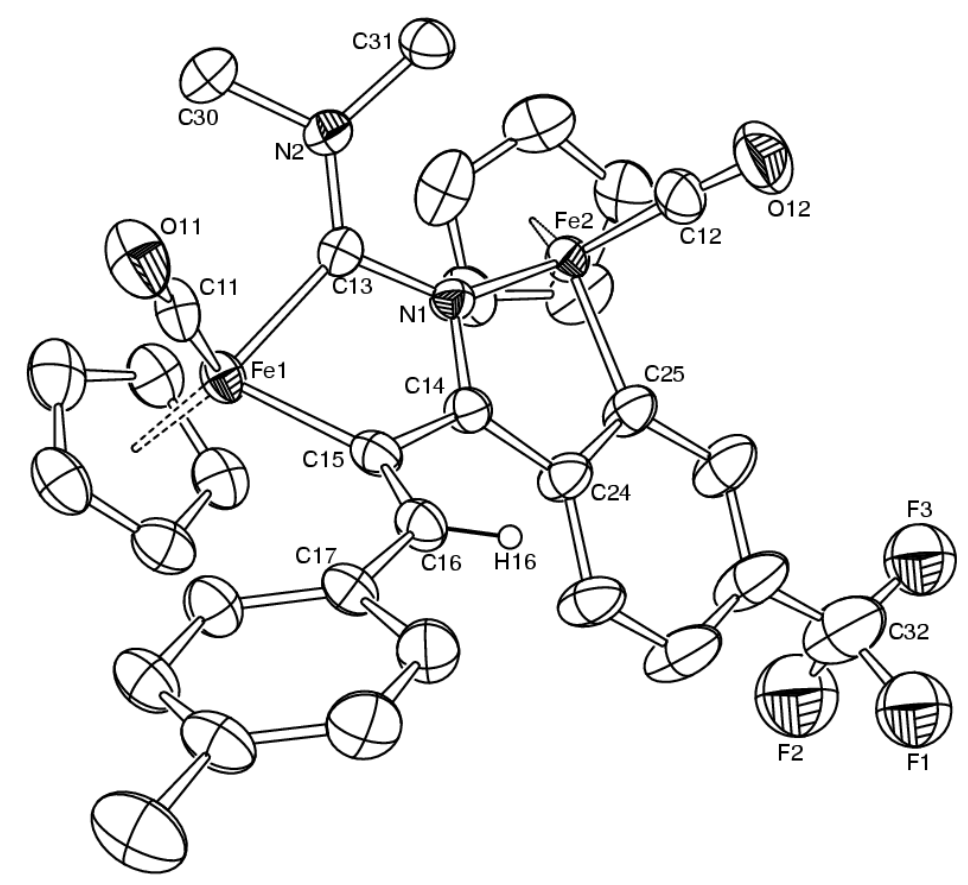

Table 1

Selected bond lengths $(\AA)$ for complexes $\mathbf{3 b}, \mathbf{3 c}, \mathbf{3 e}$ and $\mathbf{3 g}$.

\begin{tabular}{|c|c|c|c|c|c|}
\hline & $\mathbf{3 b}$ & $\begin{array}{c}\text { 3c } \\
\text { Molecule } 1 *\end{array}$ & $\begin{array}{c}\text { 3c } \\
\text { Molecule 2* }\end{array}$ & 3e & 3g \\
\hline $\mathrm{Fe}(1)-\mathrm{C}(11)$ & $1.712(8)$ & $1.704(9)$ & $1.704(8)$ & $1.7423(19)$ & $1.693(7)$ \\
\hline $\mathrm{Fe}(2)-\mathrm{C}(12)$ & $1.718(9)$ & $1.707(7)$ & $1.725(8)$ & $1.753(2)$ & $1.727(8)$ \\
\hline $\mathrm{Fe}(1)-\mathrm{C}(13)$ & $1.917(7)$ & $1.916(7)$ & $1.926(6)$ & $1.9167(18)$ & $1.923(6)$ \\
\hline $\mathrm{Fe}(1)-\mathrm{C}(15)$ & $1.977(7)$ & $1.952(7)$ & $1.986(7)$ & $1.9858(19)$ & $1.957(7)$ \\
\hline $\mathrm{Fe}(2)-\mathrm{N}(1)$ & $2.031(5)$ & $2.038(5)$ & $2.028(5)$ & $2.0395(15)$ & $2.011(5)$ \\
\hline $\mathrm{Fe}(2)-\mathrm{C}(25)$ & $1.926(7)$ & $1.933(6)$ & $1.935(6)$ & $1.9447(19)$ & $1.929(6)$ \\
\hline $\mathrm{C}(11)-\mathrm{O}(11)$ & $1.171(9)$ & $1.163(9)$ & $1.162(7)$ & $1.158(2)$ & $1.179(8)$ \\
\hline $\mathrm{C}(12)-\mathrm{O}(12)$ & $1.157(9)$ & $1.175(8)$ & $1.149(8)$ & $1.156(2)$ & $1.149(9)$ \\
\hline $\mathrm{C}(13)-\mathrm{N}(1)$ & $1.398(8)$ & $1.396(7)$ & $1.384(7)$ & $1.407(2)$ & $1.405(7)$ \\
\hline $\mathrm{C}(13)-\mathrm{N}(2)$ & $1.334(8)$ & $1.341(7)$ & $1.345(7)$ & $1.338(2)$ & $1.310(7)$ \\
\hline $\mathrm{C}(14)-\mathrm{N}(1)$ & $1.355(8)$ & $1.366(7)$ & $1.373(7)$ & $1.355(2)$ & $1.331(7)$ \\
\hline $\mathrm{C}(14)-\mathrm{C}(15)$ & $1.439(8)$ & $1.427(8)$ & $1.431(8)$ & $1.446(2)$ & $1.472(8)$ \\
\hline $\mathrm{C}(14)-\mathrm{C}(24)$ & $1.446(9)$ & $1.436(8)$ & $1.435(8)$ & $1.454(2)$ & $1.442(9)$ \\
\hline $\mathrm{C}(15)-\mathrm{C}(16)$ & $1.329(9)$ & $1.348(8)$ & $1.320(8)$ & $1.344(3)$ & $1.366(9)$ \\
\hline $\mathrm{C}(16)-\mathrm{C}(17)$ & $1.463(9)$ & $1.455(9)$ & $1.462(9)$ & $1.470(2)$ & $1.459(8)$ \\
\hline $\mathrm{C}(24)-\mathrm{C}(25)$ & $1.407(9)$ & $1.394(8)$ & $1.405(8)$ & $1.416(2)$ & $1.410(8)$ \\
\hline
\end{tabular}


* Two independent molecules are present in the unite cell.

Table 2

Selected bond angles $\left({ }^{\circ}\right)$ for complexes $\mathbf{3 b}, \mathbf{3 c}, \mathbf{3 e}$ and $\mathbf{3 g}$.

\begin{tabular}{|c|c|c|c|c|c|}
\hline & $\mathbf{3 b}$ & $\begin{array}{c}\mathbf{3 c} \\
\text { Molecule } 1^{*}\end{array}$ & $\begin{array}{c}\mathbf{3 c} \\
\text { Molecule 2* }\end{array}$ & $\mathbf{3 e}$ & $\mathbf{3 g}$ \\
\hline $\mathrm{C}(13)-\mathrm{Fe}(1)-\mathrm{C}(15)$ & $79.4(3)$ & $79.1(3)$ & $79.3(2)$ & $79.30(7)$ & $78.9(2)$ \\
\hline $\mathrm{Fe}(1)-\mathrm{C}(13)-\mathrm{N}(1)$ & $111.8(5)$ & $112.6(4)$ & $111.0(4)$ & $111.96(12)$ & $112.6(4)$ \\
\hline $\mathrm{C}(13)-\mathrm{N}(1)-\mathrm{C}(14)$ & $108.1(5)$ & $106.7(5)$ & $106.8(5)$ & $107.45(14)$ & $109.2(5)$ \\
\hline $\mathrm{N}(1)-\mathrm{C}(14)-\mathrm{C}(15)$ & $117.1(6)$ & $116.9(5)$ & $116.8(5)$ & $117.68(15)$ & $117.0(5)$ \\
\hline $\mathrm{C}(14)-\mathrm{C}(15)-\mathrm{Fe}(1)$ & $99.2(4)$ & $99.8(4)$ & $95.3(4)$ & $98.66(11)$ & $103.8(4)$ \\
\hline $\mathrm{N}(1)-\mathrm{Fe}(2)-\mathrm{C}(25)$ & $81.3(2)$ & $81.9(2)$ & $81.6(2)$ & $81.47(7)$ & $81.8(2)$ \\
\hline $\mathrm{Fe}(2)-\mathrm{C}(25)-\mathrm{C}(24)$ & $115.6(5)$ & $113.3(4)$ & $113.9(4)$ & $114.07(13)$ & $114.3(5)$ \\
\hline $\mathrm{C}(25)-\mathrm{C}(24)-\mathrm{C}(14)$ & $111.8(6)$ & $115.2(5)$ & $114.3(5)$ & $113.61(15)$ & $114.2(6)$ \\
\hline $\mathrm{C}(24)-\mathrm{C}(14)-\mathrm{N}(1)$ & $116.6(6)$ & $114.8(5)$ & $114.9(5)$ & $115.27(15)$ & $114.8(5)$ \\
\hline $\mathrm{C}(14)-\mathrm{N}(1)-\mathrm{Fe}(2)$ & $111.8(4)$ & $110.9(4)$ & $111.9(4)$ & $112.71(11)$ & $114.5(4)$ \\
\hline $\mathrm{C}(14)-\mathrm{C}(15)-\mathrm{C}(16)$ & $121.2(6)$ & $124.8(6)$ & $132.5(6)$ & $121.47(16)$ & $116.4(6)$ \\
\hline $\mathrm{Fe}(1)-\mathrm{C}(15)-\mathrm{C}(16)$ & $139.4(5)$ & $135.4(5)$ & $132.1(5)$ & $139.76(14)$ & $139.5(5)$ \\
\hline $\mathrm{C}(15)-\mathrm{C}(16)-\mathrm{C}(17)$ & $129.6(7)$ & $126.7(6)$ & $130.8(6)$ & $128.74(16)$ & $129.8(6)$ \\
\hline $\mathrm{N}(1)-\mathrm{C}(13)-\mathrm{N}(2)$ & $120.5(6)$ & $119.1(6)$ & $120.1(5)$ & $120.15(15)$ & $118.1(5)$ \\
\hline $\mathrm{Fe}(1)-\mathrm{C}(13)-\mathrm{N}(2)$ & $127.7(5)$ & $128.2(5)$ & $128.8(4)$ & $127.82(13)$ & $129.3(4)$ \\
\hline
\end{tabular}

* Two independent molecules are present in the unite cell.

Two independent molecules are present in the asymmetric unit of $\mathbf{3 c} \cdot \mathbf{0 . 5} \mathbf{C}_{\mathbf{5}} \mathbf{H}_{\mathbf{1 2}}$. All the molecules $\mathbf{3 b}, \mathbf{3 c}, \mathbf{3 e}$ and $\mathbf{3 g}$ are composed by two five member metallacycles, fused on an edge formed by a C-N bond. Both iron atoms show a tetrahedral geometry, with two coordination sites occupied by a $\mathrm{Cp}$ and a $\mathrm{CO}$ ligand, respectively. The coordination sphere of $\mathrm{Fe}(1)$ is completed by a diaminocarbene and a vinyl ligand. In agreement with this, both $\mathrm{Fe}(1)-\mathrm{C}(13)$ [1.916(7)-1.926(6) $\AA$ ] and $\mathrm{C}(13)-\mathrm{N}(2)$ [1.310(7)-1.341(7) $\AA$ ] show some double bond character, whereas $\mathrm{Fe}(1)-\mathrm{C}(15)$ $[1.952(7)-1.986(7) \AA]$ is essentially a pure $\mathrm{Fe}-\mathrm{C}\left(\mathrm{sp}^{2}\right)$ single bond. In agreement with the vinyl nature of the latter ligand, $\mathrm{C}(15)-\mathrm{C}(16)[1.320(8)-1.366(9) \AA]$ is an almost pure double bond. Interestingly, the C(13)-N(1) interaction [1.384(7)-1.407(2) $\AA$ ] has mainly the character of a single bond and, thus, the diaminocarbene carbon exhibits a considerably asymmetry in the bonding with the exo- and endo-cyclic nitrogen, probably because the latter is involved in the coordination to 
$\mathrm{Fe}(2)$ and also because of delocalisation involving $\mathrm{C}(14)$. Some $\pi$-interaction is present also in the bond between $\mathrm{Fe}(2)$ and the metallated aromatic ring [Fe(2)-C(25) 1.926(7)-1.9447(19) $\AA$ ].

In spite of the fact that the molecules present similar bond lengths and bond angles, some stereochemical differences are to be outlined. First, the $\mathrm{Cp}$ rings adopt a pseudo trans arrangement in $\mathbf{3 b}, \mathbf{3 c}$ and $\mathbf{3 e}$, whereas they can be considered cis in $\mathbf{3 g}$. Other differences consist in the configuration of the exocyclic $\mathrm{C}(15)=\mathrm{C}(16)$ bond, which adopts a $Z$ configuration in $\mathbf{3 b}, \mathbf{3 e}$ and $\mathbf{3 g}$ whereas it is $E$ in 3c. Therefore the compounds shown in Figures 1-4 should be appropriately described as Z-trans-3b, E-trans-3c, Z-trans-3e and Z-cis-3g. The different configurations of $\mathrm{C}(15)=\mathrm{C}(16)$ do not affect sensibly the rest of the molecule, whereas the different geometries of the $\mathrm{Cp}$ ligands have important effects on the conformation of the two condensed metallacycles. Thus, the ring comprising $\mathrm{Fe}(2)$ is almost planar in all the four complexes and, in fact, $\mathrm{Fe}(2), \mathrm{C}(25)$, $\mathrm{C}(24), \mathrm{C}(14)$ and $\mathrm{N}(1)$ show a very small deviation from their mean squares plane of $0.0225 \AA$ in $Z$ cis-3g and 0.0812-0.0948 $\AA$ in the trans complexes. In the case of Z-cis-3g both C(15) and C(13) lay very close to this plane [torsion angles $\mathrm{C}(15)-\mathrm{C}(14)-\mathrm{C}(24)-\mathrm{C}(25)-179.9(7){ }^{\circ}, \mathrm{C}(24)-\mathrm{C}(14)-$ $\left.\mathrm{N}(1)-\mathrm{C}(13) 168.4(5)^{\circ}\right]$, whereas they are considerably out of the plane in Z-trans-3b, E-trans-3c and Z-trans-3e [torsion angles C(15)-C(14)-C(24)-C(25) -166.02(16) - -169.6(6) ${ }^{\circ}, \mathrm{C}(24)-\mathrm{C}(14)$ $\left.\mathrm{N}(1)-\mathrm{C}(13) 141.3(5)-149.5(6)^{\circ}\right]$. These differences in the conformation of the two five member cycles seems to affect the $\mathrm{C}(14)-\mathrm{N}(1)$ bond length, which lays on the edge shared by the two rings and appears shorter for Z-cis-3g [1.331(7) A] compared to Z-trans-3b, E-trans-3c and Z-trans-3e [1.355(8)-1.373(7) $\AA$ ]. Moreover, in all the complexes the $\mathrm{C}(14)-\mathrm{N}(1)$ interaction is longer than a pure $\mathrm{C}=\mathrm{N}$ double bond and $\mathrm{N}(1)$ shows some pyramidalisation [sum angles $352.5(8)-356.1(8)^{\circ}$ in $Z$ trans-3b, E-trans-3c and Z-trans-3e; 358.9(8) ${ }^{\circ}$ in Z-cis-3g]. The Fe(2)-N(1) interaction [2.028(5)$2.0395(15) \AA$ in Z-trans-3b, E-trans-3c and Z-trans-3e; 2.011(5) $\AA$ in Z-cis-3g] is also slightly longer than expected for a coordinated imine, e.g. 1.964(3) $\AA$ in $\left[\mathrm{Fe}_{2}\{\mu-\mathrm{CN}(\mathrm{Me})(\mathrm{Xyl})\}(\mu-\right.$ $\left.\mathrm{CO})(\mathrm{CO})\left\{\mathrm{N}(\mathrm{H}) \mathrm{C}(\mathrm{C} \equiv \mathrm{CTol}) \mathrm{CMe}_{3}\right\}(\mathrm{Cp})_{2}\right]^{+}[10]$. Delocalisation effects seem to have only a minor contribution to the lengthening of $\mathrm{C}(14)-\mathrm{N}(1)$, even though they should be considered. Thus, both $\mathrm{C}(14)-\mathrm{C}(15)[1.427(8)-1.472(8) \AA]$ and C(14)-C(24) [1.435(8)-1.454(2) $\AA]$ are sensibly shorter than a single $\mathrm{C}\left(\mathrm{sp}^{2}\right)-\mathrm{C}\left(\mathrm{sp}^{2}\right)$ bond. On the basis of all these considerations, these complexes can be also described as a 1-metalla-2-amino-3-aza-5-alkylidencyclopenta-1,3-diene which acts a chelating ligand on $\mathrm{Fe}(2)$ via the endocyclic nitrogen and an orthometallated aromatic ring.

The IR spectra of 3 show the presence of a single band at $1915-1930 \mathrm{~cm}^{-1}$ for both the CO ligands. The NMR spectra of 3a-e indicate the presence in solution of two isomers in $c a$. 2-1 : 1 ratio, whereas a single species in present in the case of $\mathbf{3 f}, \mathbf{g}$. On the basis of the solid state structures, it is possible to assume that the two species present in the case of 3a-e are the E-trans 
and Z-trans isomers, whereas the complexes 3f,g maintain a Z-cis structure (Scheme 3). NMR measurements on the crystalline materials, dissolved in $\mathrm{CDCl}_{3}$, confirm this hypothesis and have helped on the assignment of the NMR data to all the different isomers.

\section{Scheme 3}

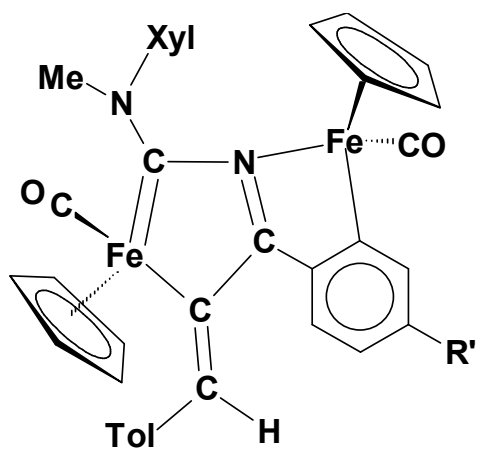

Z-trans-3a-e

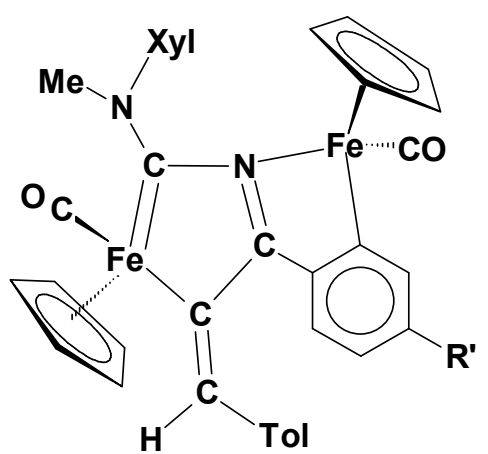

E-trans-3a-e

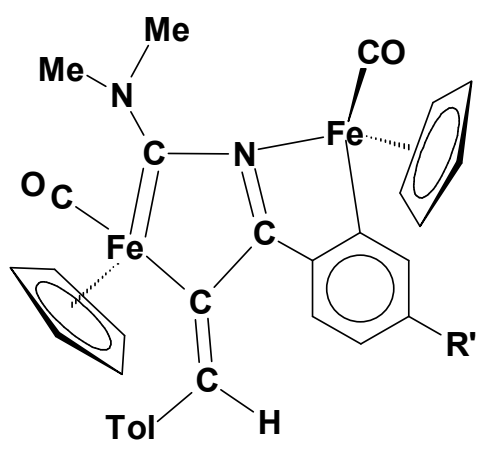

Z-cis-3f-g

The $Z$ isomers are characterized by the ${ }^{13} \mathrm{C}$ vinyl resonance due to $\mathrm{Fe}(1)-C(15)$ at $\delta 200-206$ ppm, whereas it is shifted at lower frequencies for the $E$ isomers ( $\delta 177-194 \mathrm{ppm})$. Moreover, the ${ }^{1} \mathrm{H} \mathrm{C}(16)-H(16)$ proton resonates always at higher frequencies for the $Z$ isomers than for the $E$ isomer. Other important features in the ${ }^{13} \mathrm{C}$ NMR spectra are the high frequencies resonances due to $\mathrm{Fe}(1)=C(13)(\delta 249-269 \mathrm{ppm})$ and $C(14)=\mathrm{N}(1)(\delta 198-208 \mathrm{ppm})$; the former falls within the typical range for iron diaminocarbenes. The carbon of the orthometallated aromatic ring $C(25)$ resonates at $\delta$ 150-168 ppm, whereas the exocyclic vinyl $C(16)-\mathrm{H}(16)$ shows a resonance at $\delta 130-144 \mathrm{ppm}$. Finally, it is noteworthy that in the ${ }^{1} \mathrm{H}$ NMR spectra of $\mathbf{3 f}, \mathbf{g}$ the protons of both $\mathrm{Cp}$ ligands resonante at distinct but similar frequencies $(\delta c a .4 .5 \mathrm{ppm})$, whereas they are separate by $0.5-0.6$ ppm in the complexes 3a-e which contain the Xyl group on the diaminocarbene. NOE studies indicate that the $\mathrm{Cp}$ at higher frequencies [ $\delta 4.2-4.4 \mathrm{ppm}]$ is the one close to the $\mathrm{N}(2)-\mathrm{Me}$ 
substituent [thus bound to $\mathrm{Fe}(1)$ ], whereas the $\mathrm{Xyl}$ group shields the $\mathrm{Fe}(2)-\mathrm{Cp}$ protons $[\delta 3.7-3.8$ ppm]. Similar results have been obtained on both the isomers of 3a-e, confirming that they differ only for the configuration of the exocyclic $\mathrm{C}(15)=\mathrm{C}(16)$ bond, whereas they maintain the trans arrangement of the $\mathrm{Cp}$ and the $E$ configuration of $\mathrm{C}(13)-\mathrm{N}(2)$.

The mechanism for the formation of $\mathbf{3}$ from $\mathbf{2}$ seems to be quite complex and presumably proceeds through several steps. Attempts to isolate or identify intermediate species failed. However, on the basis of previous considerations on the analogous reactions of $\left[\mathrm{M}_{2}\{\mu-\mathrm{CN}(\mathrm{Me})(\mathrm{R})\}(\mu-\right.$ $\left.\mathrm{CO})(\mathrm{CO})\left(\mathrm{NCCMe}_{3}\right)(\mathrm{Cp})_{2}\right]^{+}[\mathrm{M}=\mathrm{Fe}, \mathrm{Ru} ; \mathrm{R}=\mathrm{Xyl}, \mathrm{Bz}, \mathrm{Me}][8 \mathrm{~b}, 10]$ with $\mathrm{R}^{\prime} \mathrm{C} \equiv \mathrm{CLi}$, it appears reasonable that the reaction occurs via nucleophilic attack of TolC $\equiv \mathrm{CLi}$ on the nitrile carbon of $\mathbf{2}$, generating a $\eta^{1}$-azavinylidene intermediate of the type $\left[\mathrm{Fe}_{2}\{\mu-\mathrm{CN}(\mathrm{Me})(\mathrm{R})\}(\mu-\mathrm{CO})(\mathrm{CO})\{\mathrm{N}=\mathrm{C}(\mathrm{p}\right.$ $\left.\left.\left.\mathrm{NCC}_{6} \mathrm{H}_{4} \mathrm{R}^{\prime}\right)\left(\mathrm{C} \mathrm{CR}^{\prime}\right)\right\}(\mathrm{Cp})_{2}\right]$. Then, the azavynilidene ligand is supposed to migrate and couple with the briging aminocarbyne. These two initial steps accounts for the formation of the $C(14)-C(15)$ and $\mathrm{C}(13)-\mathrm{N}(1)$ bond, observed in 3. Further rearrangements must then take place in order to explain the formation of the final product 3. A reasonable sequence of intermediate species involved in this process can be hardly traced out, in the absence of further evidences. However some considerations can be drown: the sequence must include an orthometallation reaction, which, to the best of our knowledge, has never been described in the case of diiron complexes bridged by carbyne or carbene ligands. In general, the orthometallation reaction has been known for a long time [11], and compounds that contain an orthometallated ligand continue to be of interest for the generation of catalysts [12], compounds with interesting material properties [13], and antitumor agents [14]. A second consideration concern the fragmentation of the diiron frame $\mathrm{Fe}_{2} \mathrm{Cp}_{2}(\mu-\mathrm{CO})$ which usually appears very robust and is unaffected even by strong rearrangements, occurring on the coordinated ligands $[8-10,15]$. Breaking of the Fe-Fe bond has been previously observed only in the reaction of $\left[\mathrm{M}_{2}\{\mu-\mathrm{CN}(\mathrm{Me})(\mathrm{R})\}(\mu-\mathrm{CO})(\mathrm{CO})_{2}(\mathrm{Cp})_{2}\right]\left[\mathrm{SO}_{3} \mathrm{CF}_{3}\right](\mathrm{M}=\mathrm{Fe}, \mathrm{Ru})$ with $\mathrm{KH}$ and acetonitrile, to form a metallapyrrole ring [16].

\section{Conclusions}

The results obtained demonstrate very well the capability of diiron aminocarbyne complexes of activating coordinated nitriles with respect to the addition of acetilydes. Nucleophilic attack at the coordinated nitrile is accompanied by coupling with the bridging aminicarbyne ligand, resulting in $\mathrm{C}-\mathrm{N}$ bond formation.

Further rearrangements take place depending on the nature of the nitrile ligand, and different products are correspondingly formed (scheme 4). Complexes containing the trimetylacetonitrile 
ligand afford the allene-amminocarbene compound [10], whereas aryl-nitriles, causes the fragmentation of the Fe-Fe bond.

\section{Scheme 4}

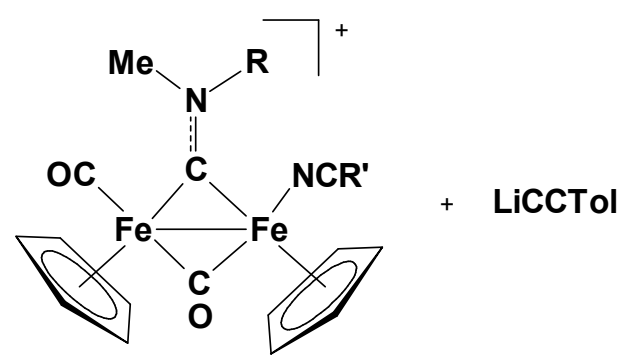

$$
\mathbf{R}^{\prime}=\text { Aryl }
$$
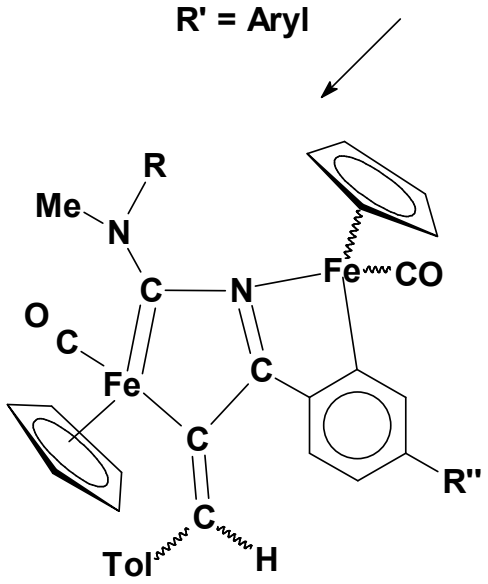

$\mathbf{R}^{\prime}=\mathrm{CMe}_{3}$

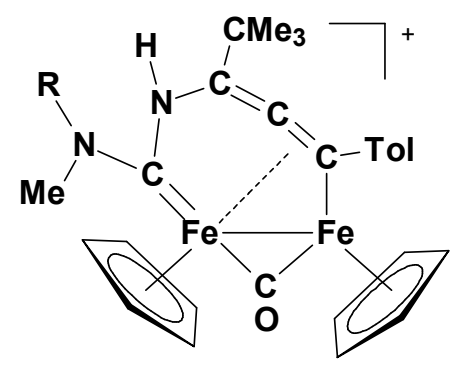

In all of the cases, it is to be outlined the role of the two adjacent metal centres in promoting intramolecular couplings of coordinated ligands, and building-up organic fragments. The metal atoms also provide stabilization to these species, through a variety of coordination modes.

\section{Experimental Section}

\subsection{General}

All reactions were carried out routinely under nitrogen using standard Schlenk techniques. Solvents were distilled immediately before use under nitrogen from appropriate drying agents. Infrared spectra were recorded on a Perkin-Elmer Spectrum 2000 FT-IR spectrophotometer and elemental analyses were performed on a ThermoQuest Flash 1112 Series EA Instrument. All NMR 
measurements were performed on Varian Gemini 300 and Varian Mercury Plus 400 instruments. The chemical shifts were referenced to internal TMS for ${ }^{1} \mathrm{H}$ and ${ }^{13} \mathrm{C}$, and to external $\mathrm{CCl}_{3} \mathrm{~F}$ for ${ }^{19} \mathrm{~F}$. The spectra were fully assigned via ${ }^{1} \mathrm{H},{ }^{13} \mathrm{C}$ correlation measured using gs-HSQC and gs-HMBC experiments [17]. Monodimensional NOE measurements were recorded using the DPFGSE-NOE sequence [18]. All chemicals were used as received from Aldrich Co., except $\left[\mathrm{Fe}_{2}\{\mu-\right.$ $\left.\mathrm{CN}(\mathrm{Me})(\mathrm{R})\}(\mu-\mathrm{CO})(\mathrm{CO})_{2}(\mathrm{Cp})_{2}\right]\left[\mathrm{SO}_{3} \mathrm{CF}_{3}\right](\mathrm{R}=\mathrm{Xyl}$, 1a; Me, 1b) [19] which were prepared by published methods. TolC $\equiv \mathrm{CLi}$ was prepared just before use from the reaction of $\mathrm{TolC} \equiv \mathrm{CH}$ with $\mathrm{Bu}^{\mathrm{n}} \mathrm{Li}$ in $\mathrm{THF}$ at $-50{ }^{\circ} \mathrm{C}$ (molar ratio $\left.1.2: 1\right)$.

4.2 Synthesis of $\left[\mathrm{Fe}_{2}\{\mu-C N(\mathrm{Me})(R)\}(\mu-\mathrm{CO})(\mathrm{CO})\left(p-N C C_{6} H_{4} R^{\prime}\right)(C p)_{2}\right]\left(R=X y l, R^{\prime}=H, 2 \boldsymbol{a} ; R=\right.$ $X y l, R^{\prime}=B r, 2 \boldsymbol{b} ; R=X y l, R^{\prime}=O M e, 2 \boldsymbol{c} ; R=X y l, R^{\prime}=C O_{2} M e, 2 d ; R=X y l, R^{\prime}=C F_{3}, 2 \boldsymbol{e} ; R=$ $M e, R^{\prime}=H, 2 f ; R=M e, R^{\prime}=C F_{3}, 2 g$ ).

p- $\mathrm{R}^{\prime} \mathrm{C}_{6} \mathrm{H}_{4} \mathrm{CN}(0.700 \mathrm{mmol})$ and $\mathrm{Me}_{3} \mathrm{NO}(52.5 \mathrm{mg}, 0.700 \mathrm{mmol})$ were added to a solution of $1(0.350 \mathrm{mmol})$ in THF $(10 \mathrm{ml})$, and the solution stirred at room temperature for 3 hours. The solvent was, then, removed in vacuo and the residue washed with $\mathrm{Et}_{2} \mathrm{O}(2 \times 10 \mathrm{ml})$ and petroleum ether $(2 \times 10 \mathrm{ml})$. The product was, therefore, further purified by filtration through celite using $\mathrm{CH}_{2} \mathrm{Cl}_{2}$ as solvent.

2a: Yield: $231.5 \mathrm{mg}(95 \%)$. Anal. Calcd. For $\mathrm{C}_{30} \mathrm{H}_{27} \mathrm{~F}_{3} \mathrm{Fe}_{2} \mathrm{~N}_{2} \mathrm{O}_{5} \mathrm{~S}$ : C, 51.75; H. 3.91; N, 4.02. Found: C, 51.54; H, 4.11, N, 4.21. IR (in $\mathrm{CH}_{2} \mathrm{Cl}_{2}, 293 \mathrm{~K}$ ): v(CO) 1985 (vs), 1823 (s); v(CN) 1587 (m), $1519(\mathrm{~m}) .{ }^{1} \mathrm{H}$ NMR $\left(\mathrm{CDCl}_{3}, 293 \mathrm{~K}\right)$ Isomer $\alpha$ : $\delta 7.41-7.04(\mathrm{~m}, 8 \mathrm{H}$, arom), 5.00, 4.22 (s, 10H, $C p), 4.35$ (s, 3H, NMe), 2.51, 1.85 (s, 6H, $M e_{2} \mathrm{C}_{6} \mathrm{H}_{3}$ ); Isomer $\beta: \delta 7.41-7.04(\mathrm{~m}, 8 \mathrm{H}$, arom), 5.10, $4.31(\mathrm{~s}, 10 \mathrm{H}, C p), 4.61(\mathrm{~s}, 3 \mathrm{H}, \mathrm{N} M e), 2.51,1.85\left(\mathrm{~s}, 6 \mathrm{H}, M e_{2} \mathrm{C}_{6} \mathrm{H}_{3}\right)$. Isomer ratio $\alpha: \beta=3: 1 .{ }^{13} \mathrm{C}$ NMR $\left(\mathrm{CDCl}_{3}, 293 \mathrm{~K}\right)$ Isomer $\alpha$ : $\delta 336.8(\mu-C), 264.2(\mu-C O), 210.6(C O), 147.8(C$-ipso Xyl), 133.6, 133.2 (C-Me Xyl), 132.6-128.8 (CH arom), $118.6(C \mathrm{~N}), 109.8$ (C-ipso Ph), 88.8, $86.6(C p)$, $53.3(\mathrm{NMe}), 18.4,17.3\left(\mathrm{Me}_{2} \mathrm{C}_{6} \mathrm{H}_{3}\right)$; Isomer $\beta$ : $\delta 337.2(\mu-C), 263.4(\mu-C \mathrm{O}), 211.2(C \mathrm{O}), 147.7(C$ ipso Xyl), 133.5, 132.9 (C-Me Xyl), 132.6-128.8 (CH arom), $118.5(C \mathrm{~N}), 109.7$ (C-ipso Ph), 88.0, $87.5(C p), 53.7(\mathrm{NMe}), 18.2,16.9\left(\mathrm{Me}_{2} \mathrm{C}_{6} \mathrm{H}_{3}\right)$.

2b: Yield: $249.6 \mathrm{mg}$ (92 \%). Anal. Calcd. For $\mathrm{C}_{30} \mathrm{H}_{26} \mathrm{BrF}_{3} \mathrm{Fe}_{2} \mathrm{~N}_{2} \mathrm{O}_{5} \mathrm{~S}$ : C, 46.48; H. 3.38; N, 3.61 . Found: C, 46.12; H, 3.01, N, 3.89. IR (in $\mathrm{CH}_{2} \mathrm{Cl}_{2}, 293 \mathrm{~K}$ ): v(CO) 1986 (vs), 1822 (s); v(CN) 1587 (m), $1519(\mathrm{~m}) .{ }^{1} \mathrm{H}$ NMR $\left(\mathrm{CDCl}_{3}, 293 \mathrm{~K}\right)$ Isomer $\alpha: \delta 7.58-7.08(\mathrm{~m}, 7 \mathrm{H}$, arom $), 5.13,4.36(\mathrm{~s}, 10 \mathrm{H}$, $C p), 4.44(\mathrm{~s}, 3 \mathrm{H}, \mathrm{NMe}), 2.64,1.96\left(\mathrm{~s}, 6 \mathrm{H}, M_{2} \mathrm{C}_{6} \mathrm{H}_{3}\right)$; Isomer $\beta: \delta 7.58-7.08(\mathrm{~m}, 7 \mathrm{H}$, arom), 5.06, $4.48(\mathrm{~s}, 10 \mathrm{H}, C p), 4.73(\mathrm{~s}, 3 \mathrm{H}, \mathrm{NMe}), 2.63,1.98\left(\mathrm{~s}, 6 \mathrm{H}, M e_{2} \mathrm{C}_{6} \mathrm{H}_{3}\right)$. Isomer ratio $\alpha: \beta=2: 1 .{ }^{13} \mathrm{C}$ 
NMR $\left(\mathrm{CDCl}_{3}, 293 \mathrm{~K}\right)$ Isomer $\alpha: \delta 337.4(\mu-C), 264.6(\mu-C O), 211.3(C O), 148.4(C$-ipso Xyl), 134.0-128.2 (CH arom $+C$-Me Xyl $+C$-Br), $118.3(C \mathrm{~N}), 109.2(C-\mathrm{CN}), 89.4,87.4(C p), 55.5$ (NMe), 19.0, $17.8\left(\mathrm{Me}_{2} \mathrm{C}_{6} \mathrm{H}_{3}\right)$; Isomer $\beta: \delta 338.1(\mu-C), 263.9(\mu-C \mathrm{O}), 211.9(C \mathrm{O}), 148.3$ (C-ipso $\mathrm{Xyl}), 134.0-128.2(C \mathrm{H}$ arom $+C$-Me Xyl $+C$-Br), $119.5(C \mathrm{~N}), 109.1(C-\mathrm{CN}), 88.5,88.2(C p), 54.4$ (NMe), 18.8, $17.4\left(\mathrm{Me}_{2} \mathrm{C}_{6} \mathrm{H}_{3}\right)$.

2c: Yield: $228.8 \mathrm{mg}(90 \%)$. Anal. Calcd. For $\mathrm{C}_{31} \mathrm{H}_{29} \mathrm{~F}_{3} \mathrm{Fe}_{2} \mathrm{~N}_{2} \mathrm{O}_{6} \mathrm{~S}$ : C, 51.27; H. 4.02; N, 3.86 . Found: C, 51.52; H, 3.79, N, 4.08. IR (in $\mathrm{CH}_{2} \mathrm{Cl}_{2}, 293 \mathrm{~K}$ ): v(CO) 1986 (vs), 1821 (s); v(CN) 1603 (m), 1509 (ms). ${ }^{1} \mathrm{H}$ NMR $\left(\mathrm{CDCl}_{3}, 293 \mathrm{~K}\right)$ Isomer $\alpha$ : $\delta 7.50-6.77$ (m, 7H, arom), 5.11, 4.33 (s, 10H, $C p), 4.44(\mathrm{~s}, 3 \mathrm{H}, \mathrm{N} M e), 3.73(\mathrm{~s}, 3 \mathrm{H}, \mathrm{OMe}), 2.65,1.98\left(\mathrm{~s}, 6 \mathrm{H}, M e_{2} \mathrm{C}_{6} \mathrm{H}_{3}\right)$; Isomer $\beta$ : $\delta 7.50-6.77(\mathrm{~m}$, $7 \mathrm{H}$, arom), 5.02, $4.47(\mathrm{~s}, 10 \mathrm{H}, C p), 4.74(\mathrm{~s}, 3 \mathrm{H}, \mathrm{NMe}), 3.72(\mathrm{~s}, 3 \mathrm{H}, \mathrm{OMe}), 2.64,1.99(\mathrm{~s}, 6 \mathrm{H}$, $\left.M e_{2} \mathrm{C}_{6} \mathrm{H}_{3}\right)$. Isomer ratio $\alpha: \beta=1.4: 1 .{ }^{13} \mathrm{C} \mathrm{NMR}\left(\mathrm{CDCl}_{3}, 293 \mathrm{~K}\right)$ Isomer $\alpha: \delta 337.8(\mu-C), 265.1$ ( $\mu$-CO), 211.3 (CO), 164.0 (C-OMe), 148.4 (C-ipso Xyl), 134.3, $115.4\left(C \mathrm{H} \mathrm{NCC}_{6} \mathrm{H}_{4} \mathrm{OMe}\right), 133.8$, 132.9 (C-Me Xyl), 130.2, 129.4, 129.3 (CH Xyl), $119.5(C \mathrm{~N}), 101.7$ (C-CN), 89.3, 87.1 (Cp), 55.9 (OMe), $55.3(\mathrm{NMe}), 19.0,17.9\left(\mathrm{Me}_{2} \mathrm{C}_{6} \mathrm{H}_{3}\right)$; Isomer $\beta$ : $\delta 338.7(\mu-C), 264.3(\mu-C \mathrm{O}), 211.9(C \mathrm{O})$, 163.9 (C-OMe), 148.3 (C-ipso Xyl), 134.6, 115.3 (CH NCC $\left.\mathrm{H}_{4} \mathrm{OMe}\right), 133.5,132.4$ (C-Me Xyl), 130.3, 129.3, 129.2 (CH Xyl), $122.7(C \mathrm{~N}), 101.6(C-\mathrm{CN}), 88.4,87.9(C p), 56.0(\mathrm{OMe}), 54.2(\mathrm{NMe})$, 18.8, $17.4\left(\mathrm{Me}_{2} \mathrm{C}_{6} \mathrm{H}_{3}\right)$.

2d: Yield: $232.3 \mathrm{mg}\left(88 \%\right.$ \%). Anal. Calcd. For $\mathrm{C}_{32} \mathrm{H}_{29} \mathrm{~F}_{3} \mathrm{Fe}_{2} \mathrm{~N}_{2} \mathrm{O}_{7} \mathrm{~S}$ : C, 50.96; H. 3.88; N, 3.71 . Found: C, 51.13; H, 3.52, N, 3.44. IR (in $\mathrm{CH}_{2} \mathrm{Cl}_{2}, 293 \mathrm{~K}$ ): v(CO) 1985 (vs), 1822 (s); v(COOMe) $1730(\mathrm{~s}) ; \mathrm{v}(\mathrm{CN}) 1519(\mathrm{~m}) .{ }^{1} \mathrm{H}$ NMR $\left(\mathrm{CDCl}_{3}, 293 \mathrm{~K}\right)$ Isomer $\alpha: \delta 7.91-7.03$ (m, 7H, arom), 5.14, $4.38(\mathrm{~s}, 10 \mathrm{H}, \mathrm{Cp}), 4.44$ (s, 3H, NMe), 3.80 (s, 3H, COOMe), 2.63, 1.95 (s, 6H, $M e_{2} \mathrm{C}_{6} \mathrm{H}_{3}$ ); Isomer $\beta$ : $\delta 7.91-7.03$ (m, 7H, arom), 5.08, 4.48 (s, 10H, Cp), 4.74 (s, 3H, NMe), 3.79 (s, 3H, COOMe), 2.63, $1.97\left(\mathrm{~s}, 6 \mathrm{H}, \mathrm{Me}_{2} \mathrm{C}_{6} \mathrm{H}_{3}\right)$. Isomer ratio $\alpha: \beta=1.4: 1 .{ }^{13} \mathrm{C} \mathrm{NMR}\left(\mathrm{CDCl}_{3}, 293 \mathrm{~K}\right)$ Isomer $\alpha: \delta 337.2(\mu-$ C), 264.3 ( $\mu$-CO), 211.3 (CO), 165.1 (COOMe), 148.4 (C-ipso Xyl), 134.6 (C-COOMe), 133.7, 132.8 (C-Me Xyl), 132.4-129.2 (CH arom), $118.2(C \mathrm{~N}), 114.2(C-\mathrm{CN}), 89.5,87.4(C p), 55.5$ (NMe), $52.9(\mathrm{COOMe}), 19.0,17.8\left(\mathrm{Me}_{2} \mathrm{C}_{6} \mathrm{H}_{3}\right)$; Isomer $\beta$ : $\delta 337.9(\mu-C), 263.6(\mu-C \mathrm{O}), 211.9(C \mathrm{O})$, 165.2 (COOMe), 148.3 (C-ipso Xyl), 134.4 (C-COOMe), 133.4, 132.7 (C-Me Xyl), 132.4-129.2 $(\mathrm{CH}$ arom), $118.2(\mathrm{CN}), 114.1(\mathrm{C}-\mathrm{CN}), 88.6,88.3(C p), 54.4(\mathrm{NMe}), 52.9(\mathrm{COOMe}), 18.7,17.4$ $\left(\mathrm{Me}_{2} \mathrm{C}_{6} \mathrm{H}_{3}\right)$.

2e: Yield: $246.1 \mathrm{mg}(92 \%)$. Anal. Calcd. For $\mathrm{C}_{31} \mathrm{H}_{26} \mathrm{~F}_{6} \mathrm{Fe}_{2} \mathrm{~N}_{2} \mathrm{O}_{5} \mathrm{~S}$ : C, 48.72; H. 3.43; N, 3.67 . Found: C, 48.39; H, 3.44, N, 3.80. IR (in $\mathrm{CH}_{2} \mathrm{Cl}_{2}, 293 \mathrm{~K}$ ): v(CO) 1985 (vs), 1822 (s); v(CN) 1520 (ms). ${ }^{1} \mathrm{H}$ NMR $\left(\mathrm{CDCl}_{3}, 293 \mathrm{~K}\right)$ Isomer $\alpha$ : $\delta 7.75-7.19$ (m, 7H, arom), 5.13, 4.39 (s, 10H, Cp), 4.44 $(\mathrm{s}, 3 \mathrm{H}, \mathrm{NMe}), 2.63,1.97\left(\mathrm{~s}, 6 \mathrm{H}, M e_{2} \mathrm{C}_{6} \mathrm{H}_{3}\right)$; Isomer $\beta: \delta 7.75-7.19(\mathrm{~m}, 7 \mathrm{H}$, arom $), 5.08,4.49(\mathrm{~s}, 10 \mathrm{H}$, 
$C p), 4.73(\mathrm{~s}, 3 \mathrm{H}, \mathrm{NMe}), 2.63,1.99\left(\mathrm{~s}, 6 \mathrm{H}, \mathrm{Me}_{2} \mathrm{C}_{6} \mathrm{H}_{3}\right)$. Isomer ratio $\alpha: \beta=1.2: 1 .{ }^{13} \mathrm{C} \mathrm{NMR}\left(\mathrm{CDCl}_{3}\right.$, $293 \mathrm{~K}$ ) Isomer $\alpha$ : $\delta 337.2(\mu-C), 264.2$ ( $\mu-C \mathrm{O}), 211.3(C \mathrm{O}), 148.4$ (C-ipso Xyl), 135.1-126.4 (CH arom $\left.+C-\mathrm{Me} \mathrm{Xyl}+C-\mathrm{CF}_{3}\right), 123.0\left(\mathrm{q},{ }^{1} \mathrm{~J}_{\mathrm{CF}}=273.6 \mathrm{~Hz}, C \mathrm{~F}_{3}\right), 117.7(C \mathrm{~N}), 114.0(C-\mathrm{CN}), 89.4,87.5$ $(C p), 55.5(\mathrm{NMe}), 18.9,17.8\left(\mathrm{Me}_{2} \mathrm{C}_{6} \mathrm{H}_{3}\right)$; Isomer $\beta$ : $\delta 337.9(\mu-C), 263.6(\mu-C \mathrm{O}), 211.9(C \mathrm{O}), 148.3$ (C-ipso Xyl), 135.1-126.4 (CH arom $+C$-Me Xyl $\left.+C-\mathrm{CF}_{3}\right), 123.1\left(\mathrm{q},{ }^{1} \mathrm{~J}_{\mathrm{CF}}=273.6 \mathrm{~Hz}, C \mathrm{~F}_{3}\right), 117.7$ $(C \mathrm{~N}), 114.0(C-\mathrm{CN}), 88.6,88.3(C p), 54.4(\mathrm{NMe}), 18.7,17.4\left(\mathrm{Me}_{2} \mathrm{C}_{6} \mathrm{H}_{3}\right) .{ }^{19} \mathrm{~F} \mathrm{NMR}\left(\mathrm{CDCl}_{3}, 293 \mathrm{~K}\right)$ Isomer $\alpha$ : $\delta$-64.04; Isomer $\beta$ : $\delta$-63.91.

2f: Yield: $180.3 \mathrm{mg}(85 \%)$. Anal. Calcd. For $\mathrm{C}_{23} \mathrm{H}_{21} \mathrm{~F}_{3} \mathrm{Fe}_{2} \mathrm{~N}_{2} \mathrm{O}_{5} \mathrm{~S}$ : C, 45.58; H. 3.49; N, 4.62. Found: C, 45.64; H, 3.23, N, 4.85. IR (in $\mathrm{CH}_{2} \mathrm{Cl}_{2}, 293 \mathrm{~K}$ ): v(CO) 1982 (vs), 1816 (s); v(CN) 1589 (m). ${ }^{1} \mathrm{H}$ NMR $\left(\mathrm{CDCl}_{3}, 293 \mathrm{~K}\right): \delta 7.52-7.19(\mathrm{~m}, 5 \mathrm{H}, \mathrm{Ph}), 4.98,4.91(\mathrm{~s}, 10 \mathrm{H}, C p), 4.65,4.24(6 \mathrm{H}, \mathrm{s}$, $\left.\mathrm{N} M e_{2}\right)$.

2g: Yield: $219.4 \mathrm{mg}(93 \%)$. Anal. Calcd. For $\mathrm{C}_{24} \mathrm{H}_{20} \mathrm{~F}_{6} \mathrm{Fe}_{2} \mathrm{~N}_{2} \mathrm{O}_{5} \mathrm{~S}$ : C, 42.76; H. 2.99; N, 4.16. Found: C, 42.98; H, 2.72, N, 4.34. IR (in $\mathrm{CH}_{2} \mathrm{Cl}_{2}, 293 \mathrm{~K}$ ): v(CO) 1981 (vs), 1816 (s); v(CN) 1589 (ms). ${ }^{1} \mathrm{H}$ NMR $\left(\mathrm{CDCl}_{3}, 293 \mathrm{~K}\right): \delta 8.10-7.71$ (m, 4H, arom), 5.29, 5.21 (s, 10H, Cp), 4.77, 4.43 (s, $\left.6 \mathrm{H}, \mathrm{NMe})_{2}\right){ }^{13} \mathrm{C} \mathrm{NMR}\left(\mathrm{CDCl}_{3}, 293 \mathrm{~K}\right): \delta 329.3(\mu-C), 266.6(\mu-C \mathrm{O}), 212.9(C \mathrm{O}), 134.8\left(\mathrm{q},{ }^{2} \mathrm{~J}_{\mathrm{CF}}=\right.$ $\left.8.4 \mathrm{~Hz}, C-\mathrm{CF}_{3}\right), 135.0,134.7\left(C \mathrm{H} \mathrm{o}-\mathrm{NCC}_{6} \mathrm{H}_{4} \mathrm{CF}_{3}\right), 127.8,127.6\left(\mathrm{q},{ }^{3} \mathrm{~J}_{\mathrm{CF}}=4.2\right.$ and $3.4 \mathrm{~Hz}, C \mathrm{H} \mathrm{m}-$ $\left.\mathrm{NCC}_{6} \mathrm{H}_{4} \mathrm{CF}_{3}\right), 124.7\left(\mathrm{q},{ }^{1} \mathrm{~J}_{\mathrm{CF}}=272.3 \mathrm{~Hz}, C \mathrm{~F}_{3}\right), 123.0\left(\mathrm{q},{ }^{1} \mathrm{~J}_{\mathrm{CF}}=321.8 \mathrm{~Hz}, C_{3} \mathrm{SO}_{3}{ }^{-}\right), 118.8(C \mathrm{~N})$, 117.6 (C-CN), 90.4, $89.0(C p), 54.8,54.0\left(\mathrm{NMe}_{2}\right)$.

4.3 Synthesis of $\left[\mathrm{Fe}(\mathrm{Cp})(\mathrm{CO})\left\{\mu-\eta^{2}: \eta^{2}-\mathrm{C}[N(\mathrm{Me})(\mathrm{R})] N=\mathrm{C}\left(\mathrm{C}_{6} \mathrm{H}_{3} \mathrm{R}^{\prime}\right) \mathrm{C}=\mathrm{CH}(\mathrm{Tol})\right\} \mathrm{Fe}(\mathrm{Cp})(\mathrm{CO})\right](\mathrm{R}=$ $X y l, R^{\prime}=H, 3 a ; R=X y l, R^{\prime}=B r, 3 b ; R=X y l, R^{\prime}=O M e, 3 c ; R=X y l, R^{\prime}=\mathrm{CO}_{2} \mathrm{Me}, 3 \boldsymbol{d} ; R=X y l$, $\left.R^{\prime}=C F_{3}, 3 \boldsymbol{e} ; R=M e, R^{\prime}=H, 3 f ; R=M e, R^{\prime}=C F_{3}, 3 \boldsymbol{g}\right)$.

A solution of TolCCLi $(1.45 \mathrm{mmol})$ was prepared by addition at $-50^{\circ} \mathrm{C}$ of $\mathrm{Bu}^{\mathrm{n}} \mathrm{Li}(0.580 \mathrm{ml}$, $2.5 \mathrm{M}$ in hexane, $1.45 \mathrm{mmol})$ to TolCCH $(0.200 \mathrm{ml}, 1.58 \mathrm{mmol})$ dissolved in THF $(5 \mathrm{ml})$, and the mixture stirred at room temperature for one hour. This solution was, then, added at $-50{ }^{\circ} \mathrm{C}$ to 2 $(0.720 \mathrm{mmol})$ dissolved in THF $(10 \mathrm{ml})$, and the mixture stirred at room temperature for 1 hour. The resulting red solution was, therefore, filtered through $\mathrm{Al}_{2} \mathrm{O}_{3}$ in order to remove the excess of TolCCLi, and the solvent removed from the filtrated under reduced pressure. The residue was, then, dissolved in $\mathrm{CH}_{2} \mathrm{Cl}_{2}(3 \mathrm{ml})$ and chromatographed through $\mathrm{Al}_{2} \mathrm{O}_{3}$ - The final product was obtained as a red fraction using $\mathrm{CH}_{2} \mathrm{Cl}_{2}$ as eluent.

3a: Yield: $290.9 \mathrm{mg}$ (61 \%). Anal. Calcd. For $\mathrm{C}_{38} \mathrm{H}_{34} \mathrm{Fe}_{2} \mathrm{~N}_{2} \mathrm{O}_{2}:$ C, 68.90; H. 5.17; N, 4.23. Found: C, 68.59; H, 5.36, N, 4.01. IR (in $\mathrm{CH}_{2} \mathrm{Cl}_{2}, 293 \mathrm{~K}$ ): v(CO) 1915 (vs); v(CN) 1572 (w), 1508 (m). ${ }^{1} \mathrm{H}$ 
NMR $\left(\mathrm{CDCl}_{3}, 293 \mathrm{~K}\right)$ Isomer $E: \delta 7.77-6.69(\mathrm{~m}, 11 \mathrm{H}$, arom $), 7.26(\mathrm{~s}, 1 \mathrm{H},=\mathrm{CH}), 4.24,3.72(\mathrm{~s}, 10 \mathrm{H}$, $C p), 3.40(\mathrm{~s}, 3 \mathrm{H}, \mathrm{NMe}), 2.69,2.17\left(\mathrm{~s}, 6 \mathrm{H}, M e_{2} \mathrm{C}_{6} \mathrm{H}_{3}\right), 2.39$ (s, 3H, $\left.M e \mathrm{C}_{6} \mathrm{H}_{4}\right)$; Isomer Z: $\delta$ 7.77-6.69 (m, 11H, arom), $7.61(\mathrm{~s}, 1 \mathrm{H},=\mathrm{CH}), 4.39,3.76(\mathrm{~s}, 10 \mathrm{H}, C p), 3.54(\mathrm{~s}, 3 \mathrm{H}, \mathrm{NMe}), 2.47,2.26(\mathrm{~s}, 6 \mathrm{H}$,

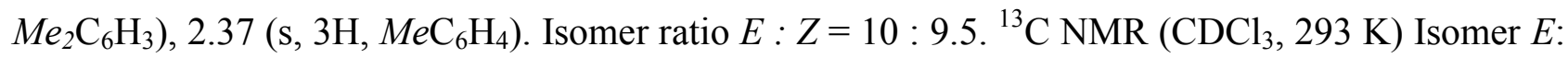
$\delta 253.9(\mathrm{Fe}=C), 223.1,222.5(C O), 203.4(C=\mathrm{N}), 189.7(\mathrm{Fe}-C=\mathrm{CH}), 168.6\left(\mathrm{Fe}-C \mathrm{C}_{6} \mathrm{H}_{4}\right), 145.1(C-$ ipso Tol), 144.3 (C-ipso Xyl), 136.0 (=CH), 135.3, 134.8 (C-Me Xyl), 136.8 (C-Me Tol), 133.9 (Cipso $\left.\mathrm{C}_{6} \mathrm{H}_{4}\right), 132.7-122.5\left(\mathrm{CH}\right.$ arom), 84.9, $82.3(\mathrm{Cp}), 50.2(\mathrm{NMe}), 21.7\left(\mathrm{MeC}_{6} \mathrm{H}_{4}\right), 19.4,19.2$ $\left(M_{2} \mathrm{C}_{6} \mathrm{H}_{3}\right)$; Isomer $\mathrm{Z}: \delta 256.4(\mathrm{Fe}=C), 221.8,221.5(C \mathrm{O}), 203.6(C=\mathrm{N}), 201.0(\mathrm{Fe}-C=\mathrm{CH}), 166.6$ (Fe- $\left.C \mathrm{C}_{6} \mathrm{H}_{4}\right), 145.4$ ( $C$-ipso Tol), 144.5 ( $C$-ipso Xyl), 139.3 (=CH), 135.4, 134.5 ( $C$-Me Xyl), 137.1 (C-Me Tol), $139.8\left(C\right.$-ipso $\left.\mathrm{C}_{6} \mathrm{H}_{4}\right), 132.7-122.5(C \mathrm{H}$ arom), 85.2, $82.5(C p), 51.0(\mathrm{~N} M e), 22.0$ $\left(\mathrm{MeC}_{6} \mathrm{H}_{4}\right), 20.1,19.8\left(\mathrm{Me}_{2} \mathrm{C}_{6} \mathrm{H}_{3}\right)$.

3b: Yield: 298.9 mg (56 \%). Anal. Calcd. For $\mathrm{C}_{38} \mathrm{H}_{33} \mathrm{BrFe}_{2} \mathrm{~N}_{2} \mathrm{O}_{2}$ : C, 61.57; H. 4.49; N, 3.78. Found: C, 61.85; H, 4.09, N, 3.85. IR (in $\mathrm{CH}_{2} \mathrm{Cl}_{2}, 293 \mathrm{~K}$ ): v(CO) 1918 (vs); v(CN) 1554 (m), 1508 (m). ${ }^{1} \mathrm{H}$ NMR $\left(\mathrm{CDCl}_{3}, 293 \mathrm{~K}\right)$ Isomer $E$ : $\delta 7.83\left(\mathrm{~s}, 1 \mathrm{H}, \mathrm{CH}\right.$ o- $\left.\mathrm{C}_{6} \mathrm{H}_{3} \mathrm{Br}\right), 7.77-6.86$ (m, 9H, arom), 6.79 (s, $1 \mathrm{H},=\mathrm{CH}), 4.31,3.78(\mathrm{~s}, 10 \mathrm{H}, C p), 3.42(\mathrm{~s}, 3 \mathrm{H}, \mathrm{N} M e), 2.73,2.18\left(\mathrm{~s}, 6 \mathrm{H}, M e_{2} \mathrm{C}_{6} \mathrm{H}_{3}\right), 2.40(\mathrm{~s}, 3 \mathrm{H}$, $\left.M_{e} \mathrm{C}_{6} \mathrm{H}_{4}\right)$; Isomer $\mathrm{Z}: \delta 8.00\left(\mathrm{~s}, 1 \mathrm{H}, \mathrm{CH}\right.$ o- $\left.\mathrm{C}_{6} \mathrm{H}_{3} \mathrm{Br}\right), 7.77-6.86(\mathrm{~m}, 9 \mathrm{H}$, arom $), 7.61(\mathrm{~s}, 1 \mathrm{H},=\mathrm{CH})$, 4.44, 3.82 (s, 10H, Cp), 3.56 (s, 3H, NMe), 2.52, 2.21 (s, 6H, Me $\left.{ }_{2} \mathrm{C}_{6} \mathrm{H}_{3}\right), 2.33\left(\mathrm{~s}, 3 \mathrm{H}, M e \mathrm{C}_{6} \mathrm{H}_{4}\right)$. Isomer ratio $E: Z=10: 5.9 .{ }^{13} \mathrm{C} \mathrm{NMR}\left(\mathrm{CDCl}_{3}, 293 \mathrm{~K}\right)$ Isomer $E: \delta 252.9(\mathrm{Fe}=C), 222.8,222.3$ (CO), $202.9(C=\mathrm{N}), 186.2(\mathrm{Fe}-C=\mathrm{CH}), 168.4\left(\mathrm{Fe}-\mathrm{C} \mathrm{C}_{6} \mathrm{H}_{3} \mathrm{Br}\right), 145.9\left(C \mathrm{H} \mathrm{o}-\mathrm{C}_{6} \mathrm{H}_{3} \mathrm{Br}\right), 145.0-118.2$ (arom), $130.1(=C H), 84.9,82.2(C p), 50.2(\mathrm{NMe}), 21.9\left(M_{e} \mathrm{C}_{6} \mathrm{H}_{4}\right), 19.7,19.1\left(M_{2} \mathrm{C}_{6} \mathrm{H}_{3}\right)$; Isomer $Z$ : $\delta 256.8(\mathrm{Fe}=C), 221.7,221.2(C \mathrm{O}), 205.9(\mathrm{Fe}-C=\mathrm{CH}), 202.0(C=\mathrm{N}), 166.5\left(\mathrm{Fe}-C \mathrm{C}_{6} \mathrm{H}_{3} \mathrm{Br}\right), 146.1$ $\left(C \mathrm{H}\right.$ o- $\left.\mathrm{C}_{6} \mathrm{H}_{3} \mathrm{Br}\right), 145.0-118.2$ (arom), $139.8(=C \mathrm{H}), 85.2,82.4(C p), 51.1(\mathrm{NMe}), 21.7\left(M e \mathrm{C}_{6} \mathrm{H}_{4}\right)$, 20.0, $19.4\left(\mathrm{Me}_{2} \mathrm{C}_{6} \mathrm{H}_{3}\right)$.

3c: Yield: $289.2 \mathrm{mg}\left(58 \%\right.$ \%). Anal. Calcd. For $\mathrm{C}_{39} \mathrm{H}_{36} \mathrm{Fe}_{2} \mathrm{~N}_{2} \mathrm{O}_{3}$ : C, 67.65; H. 5.24; N, 4.05. Found: C, 67.39; H, 5.47, N, 4.39. IR (in $\mathrm{CH}_{2} \mathrm{Cl}_{2}, 293 \mathrm{~K}$ ): v(CO) 1915 (vs); v(CN) 1575 (m), 1509 (m). ${ }^{1} \mathrm{H}$ $\mathrm{NMR}\left(\mathrm{CDCl}_{3}, 293 \mathrm{~K}\right)$ : Isomer $E$ : $\delta 7.86-6.33\left(\mathrm{~m}, 9 \mathrm{H}\right.$, arom), $7.60\left(\mathrm{~s}, 1 \mathrm{H}, \mathrm{CH}\right.$ o- $\left.\mathrm{C}_{6} \mathrm{H}_{3} \mathrm{OMe}\right), 6.71(\mathrm{~s}$, $1 \mathrm{H},=\mathrm{CH}), 4.28,3.78(\mathrm{~s}, 10 \mathrm{H}, C p), 3.82(\mathrm{~s}, 3 \mathrm{H}, \mathrm{OMe}), 3.47(\mathrm{~s}, 3 \mathrm{H}, \mathrm{NMe}), 2.59,2.39(\mathrm{~s}, 6 \mathrm{H}$, $\left.M e_{2} \mathrm{C}_{6} \mathrm{H}_{3}\right), 2.30\left(\mathrm{~s}, 3 \mathrm{H}, M e \mathrm{C}_{6} \mathrm{H}_{4}\right)$; Isomer $\mathrm{Z}: \delta 7.86-6.33(\mathrm{~m}, 9 \mathrm{H}$, arom), 7.82 (s, $1 \mathrm{H}, \mathrm{CH}$ o$\left.\mathrm{C}_{6} \mathrm{H}_{3} \mathrm{OMe}\right), 7.35(\mathrm{~s}, 1 \mathrm{H},=\mathrm{CH}), 4.41,3.78(\mathrm{~s}, 10 \mathrm{H}, C p), 3.90(\mathrm{~s}, 3 \mathrm{H}, \mathrm{OMe}), 3.56(\mathrm{~s}, 3 \mathrm{H}, \mathrm{NMe}), 2.75$, $2.16\left(\mathrm{~s}, 6 \mathrm{H}, \mathrm{Me}_{2} \mathrm{C}_{6} \mathrm{H}_{3}\right), 2.42\left(\mathrm{~s}, 3 \mathrm{H}, \mathrm{MeC}_{6} \mathrm{H}_{4}\right)$. Isomer ratio $E: Z=1: 1.04 .{ }^{13} \mathrm{C} \mathrm{NMR}\left(\mathrm{CDCl}_{3}, 293\right.$ $\mathrm{K})$ : Isomer $E$ : $\delta 257.0(\mathrm{Fe}=C), 223.3,222.1(C \mathrm{O}), 208.0(C=\mathrm{N}), 194.3(\mathrm{Fe}-C=\mathrm{CH}), 168.9(C-\mathrm{OMe})$, $158.2\left(\mathrm{Fe}-\mathrm{C} \mathrm{C}_{6} \mathrm{H}_{3} \mathrm{OMe}\right), 145.4$ ( $C$-ipso Xyl), 139.8-111.4 (arom $\left.+=C H\right), 84.6,82.5(C p), 55.3$ $(\mathrm{OMe}), 50.9(\mathrm{NMe}), 21.4\left(\mathrm{MeC}_{6} \mathrm{H}_{4}\right), 20.0,19.7\left(\mathrm{Me}_{2} \mathrm{C}_{6} \mathrm{H}_{3}\right)$; Isomer $Z$ : $\delta 256.0(\mathrm{Fe}=C), 222.5,222.2$ 
(CO), $206.0(\mathrm{Fe}-C=\mathrm{CH}), 203.6(C=\mathrm{N}), 166.9\left(C\right.$-OMe), $158.4\left(\mathrm{Fe}-C \mathrm{C}_{6} \mathrm{H}_{3} \mathrm{OMe}\right), 145.3$ ( $C$-ipso $\mathrm{Xyl})$, 139.8-111.4 (arom $+=C H), 85.1,82.3(C p), 55.5(\mathrm{OMe}), 50.2(\mathrm{NMe}), 21.7\left(\mathrm{MeC}_{6} \mathrm{H}_{4}\right), 19.4$, $19.2\left(\mathrm{Me}_{2} \mathrm{C}_{6} \mathrm{H}_{3}\right)$.

3d: Yield: $280.1 \mathrm{mg}$ (54 \%). Anal. Calcd. For $\mathrm{C}_{40} \mathrm{H}_{36} \mathrm{Fe}_{2} \mathrm{~N}_{2} \mathrm{O}_{4}$ : C, 66.69; H. 5.04; N, 3.89. Found: C, 66.92; H, 5.29, N, 3.56. IR (in $\mathrm{CH}_{2} \mathrm{Cl}_{2}, 293 \mathrm{~K}$ ): v(CO) 1917 (vs); v(COOMe) 1716 (m); v(CN) $1508(\mathrm{~m}) .{ }^{1} \mathrm{H}$ NMR $\left(\mathrm{CDCl}_{3}, 293 \mathrm{~K}\right)$ Isomer $E: \delta 8.15-6.96(\mathrm{~m}, 9 \mathrm{H}$, arom $), 7.67$ (s, $1 \mathrm{H}, \mathrm{CH}$ o$\left.\mathrm{C}_{6} \mathrm{H}_{3} \mathrm{COOMe}\right), 6.78(\mathrm{~s}, 1 \mathrm{H},=\mathrm{CH}), 4.26,3.74(\mathrm{~s}, 10 \mathrm{H}, \mathrm{Cp}), 3.88(\mathrm{~s}, 3 \mathrm{H}, \mathrm{COOMe}), 3.33(\mathrm{~s}, 3 \mathrm{H}$, $\mathrm{NMe}$ ), 2.69, $2.14\left(\mathrm{~s}, 6 \mathrm{H}, M_{2} \mathrm{C}_{6} \mathrm{H}_{3}\right), 2.27\left(\mathrm{~s}, 3 \mathrm{H}, M e \mathrm{C}_{6} \mathrm{H}_{4}\right)$; Isomer $Z: \delta 8.22(\mathrm{~s}, 1 \mathrm{H}, \mathrm{CH}$ o$\mathrm{C}_{6} \mathrm{H}_{3} \mathrm{COOMe}$ ), 8.15-6.96 (m, 9H, arom), 7.77 (s, 1H, =CH), 4.40, 3.80 (s, 10H, Cp), 3.93 (s, 3H, $\mathrm{COOMe}$ ), $3.53(\mathrm{~s}, 3 \mathrm{H}, \mathrm{NMe}), 2.44,2.17$ (s, 6H, $\left.M e_{2} \mathrm{C}_{6} \mathrm{H}_{3}\right), 2.37$ (s, 3H, $\left.M e \mathrm{C}_{6} \mathrm{H}_{4}\right)$. Isomer ratio $E: Z$ $=5: 3 .{ }^{13} \mathrm{C} \mathrm{NMR}\left(\mathrm{CDCl}_{3}, 293 \mathrm{~K}\right)$ Isomer $E: \delta 249.0(\mathrm{Fe}=C), 222.8,222.3(C \mathrm{O}), 197.5(C=\mathrm{N})$, $177.1(\mathrm{Fe}-C=\mathrm{CH}), 168.3$ (COOMe), 150.2 (Fe- $\left.C \mathrm{C}_{6} \mathrm{H}_{3} \mathrm{COOMe}\right), 144.7$ ( $C$-ipso Xyl), 143.9 (=CH), 139.7-123.3 (arom), 85.2, 82.1 (Cp), 52.2 (COOMe), 49.7 (NMe), $21.6\left(\mathrm{MeC}_{6} \mathrm{H}_{4}\right), 19.6,19.1$ $\left(M_{2} \mathrm{C}_{6} \mathrm{H}_{3}\right)$; Isomer $\mathrm{Z}: \delta 255.6(\mathrm{Fe}=C), 221.5,220.8(C \mathrm{O}), 201.9(\mathrm{Fe}-\mathrm{C}=\mathrm{CH}), 199.7(C=\mathrm{N}), 168.7$ (COOMe), 150.9 (Fe- $\left.C \mathrm{C}_{6} \mathrm{H}_{3} \mathrm{COOMe}\right), 144.3$ (C-ipso Xyl), 144.0 (=CH), 139.7-123.3 (arom), 85.3, $82.4(C p), 52.4(\mathrm{COOMe}), 51.0(\mathrm{NMe}), 21.3\left(\mathrm{MeC}_{6} \mathrm{H}_{4}\right), 20.0,19.4\left(\mathrm{Me}_{2} \mathrm{C}_{6} \mathrm{H}_{3}\right)$.

3e: Yield: $315.5 \mathrm{mg}(60 \%)$. Anal. Calcd. For $\mathrm{C}_{39} \mathrm{H}_{33} \mathrm{~F}_{3} \mathrm{Fe}_{2} \mathrm{~N}_{2} \mathrm{O}_{2}$ : C, 64.13; H. 4.55; N, 3.84. Found: C, 64.41; H, 4.17, N, 4.01. IR (in $\mathrm{CH}_{2} \mathrm{Cl}_{2}, 293 \mathrm{~K}$ ): v(CO) 1921 (vs); v(CN) 1508 (m). ${ }^{1} \mathrm{H}$ NMR $\left(\mathrm{CDCl}_{3}, 293 \mathrm{~K}\right)$ Isomer $E$ : $\delta 8.08-6.70(\mathrm{~m}, 10 \mathrm{H}$, arom $), 6.83(\mathrm{~s}, 1 \mathrm{H},=\mathrm{CH}), 4.30,3.77(\mathrm{~s}, 10 \mathrm{H}, C p)$, 3.37 (s, 3H, NMe), 2.71, $2.17\left(\mathrm{~s}, 6 \mathrm{H}, M e_{2} \mathrm{C}_{6} \mathrm{H}_{3}\right), 2.31\left(\mathrm{~s}, 3 \mathrm{H}, M e \mathrm{C}_{6} \mathrm{H}_{4}\right)$; Isomer $Z: \delta 8.08-6.70(\mathrm{~m}$, $10 \mathrm{H}$, arom), $7.84(\mathrm{~s}, 1 \mathrm{H},=\mathrm{CH}), 4.45,3.83(\mathrm{~s}, 10 \mathrm{H}, C p), 3.57(\mathrm{~s}, 3 \mathrm{H}, \mathrm{NMe}), 2.45,2.24(\mathrm{~s}, 6 \mathrm{H}$,

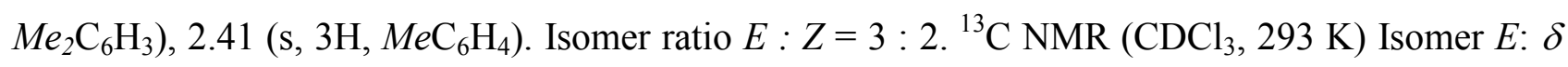
$249.1(\mathrm{Fe}=C), 222.5,222.0(C \mathrm{O}), 198.2(C=\mathrm{N}), 177.2(\mathrm{Fe}-C=\mathrm{CH}), 167.8\left(\mathrm{Fe}-C \mathrm{C}_{6} \mathrm{H}_{3} \mathrm{CF}_{3}\right), 148.5$ ( $C$-ipso $\mathrm{C}_{6} \mathrm{H}_{3} \mathrm{CF}_{3}$ ), 144.4 (C-ipso Xyl), 140.0-118.8 (arom $\left.+C \mathrm{~F}_{3}\right), 130.7(=C \mathrm{H}), 84.8,81.8(C p)$, $50.8(\mathrm{NMe}), 21.3\left(\mathrm{MeC}_{6} \mathrm{H}_{4}\right), 19.3,18.8\left(\mathrm{Me}_{2} \mathrm{C}_{6} \mathrm{H}_{3}\right)$; Isomer $Z: \delta 255.1(\mathrm{Fe}=C), 221.1,220.4(C \mathrm{O})$, $202.5(\mathrm{Fe}-C=\mathrm{CH}), 199.6(C=\mathrm{N}), 166.2\left(\mathrm{Fe}-\mathrm{C} \mathrm{C}{ }_{6} \mathrm{H}_{3} \mathrm{CF}_{3}\right), 149.4\left(C\right.$-ipso $\left.\mathrm{C}_{6} \mathrm{H}_{3} \mathrm{CF}_{3}\right), 144.9(C$-ipso Xyl), 140.0-118.8 (arom $\left.+C \mathrm{~F}_{3}\right), 139.1(=C \mathrm{H}), 85.0,82.1(C p), 49.5(\mathrm{NMe}), 21.6\left(M_{6} \mathrm{C}_{6} \mathrm{H}_{4}\right), 19.7$, $19.1\left(\mathrm{Me}_{2} \mathrm{C}_{6} \mathrm{H}_{3}\right) .{ }^{19} \mathrm{~F} \mathrm{NMR}\left(\mathrm{CDCl}_{3}, 293 \mathrm{~K}\right)$ Isomer $E$ : $\delta$-62.72; Isomer $Z$ : $\delta$-62.75.

3f: Yield: $234.9 \mathrm{mg}(57 \%)$. Anal. Calcd. For $\mathrm{C}_{31} \mathrm{H}_{28} \mathrm{Fe}_{2} \mathrm{~N}_{2} \mathrm{O}_{2}$ : C, 65.06; H. 4.93; N, 4.90. Found: C, 65.27; H, 4.69, N, 5.02. IR (in $\mathrm{CH}_{2} \mathrm{Cl}_{2}, 293 \mathrm{~K}$ ): v(CO) 1926 (vs); v(CN) 1508 (m). ${ }^{1} \mathrm{H}$ NMR $\left(\mathrm{CDCl}_{3}, 293 \mathrm{~K}\right): \delta 8.06-6.55(\mathrm{~m}, 8 \mathrm{H}$, arom $), 7.87(\mathrm{~s}, 1 \mathrm{H},=\mathrm{CH}), 4.57,4.49(\mathrm{~s}, 10 \mathrm{H}, C p), 3.63,3.58$ $(\mathrm{s}, 6 \mathrm{H}, \mathrm{NMe} 2), 2.39\left(\mathrm{~s}, 3 \mathrm{H}, \mathrm{MeC}_{6} \mathrm{H}_{4}\right) \cdot{ }^{13} \mathrm{C} \mathrm{NMR}\left(\mathrm{CDCl}_{3}, 293 \mathrm{~K}\right): \delta 268.3(\mathrm{Fe}=C), 220.8,218.8$ $(C \mathrm{O}), 208.5(C=\mathrm{N}), 197.1(\mathrm{Fe}-C=\mathrm{CH}), 163.8\left(\mathrm{Fe}-C \mathrm{C}_{6} \mathrm{H}_{4}\right), 144.3(=C \mathrm{H}), 142.9\left(C\right.$-ipso $\left.\mathrm{C}_{6} \mathrm{H}_{4}\right)$, 
141.1 ( $C$-ipso Tol), 138.5 (C-Me Tol), 132.6-119.1 (CH arom), 84.0, 82.8 (Cp), 49.8, $42.6\left(\mathrm{NMe}_{2}\right)$, $21.6\left(\mathrm{MeC}_{6} \mathrm{H}_{4}\right)$.

3g: Yield: $295.0 \mathrm{mg}\left(64\right.$ \%). Anal. Calcd. For $\mathrm{C}_{32} \mathrm{H}_{27} \mathrm{~F}_{3} \mathrm{Fe}_{2} \mathrm{~N}_{2} \mathrm{O}_{2}$ : C, 60.03; H. 4.25; N, 4.38. Found: C, 60.29; H, 4.02, N, 4.05. IR (in $\mathrm{CH}_{2} \mathrm{Cl}_{2}, 293 \mathrm{~K}$ ): v(CO) 1930 (vs); v(CN) 1539 (w), 1507 (m). ${ }^{1} \mathrm{H}$ NMR $\left(\mathrm{CDCl}_{3}, 293 \mathrm{~K}\right): \delta 8.09(\mathrm{~s}, 1 \mathrm{H},=\mathrm{CH}), 7.91-7.15(\mathrm{~m}, 7 \mathrm{H}$, arom $), 4.57,4.51(\mathrm{~s}, 10 \mathrm{H}, C p), 3.64$, $3.58(\mathrm{~s}, 6 \mathrm{H}, \mathrm{NMe}), 2.38\left(\mathrm{~s}, 3 \mathrm{H}, \mathrm{MeC}_{6} \mathrm{H}_{4}\right) .{ }^{13} \mathrm{C} \mathrm{NMR}\left(\mathrm{CDCl}_{3}, 293 \mathrm{~K}\right): \delta 269.2(\mathrm{Fe}=C), 220.5,218.1$ $(C \mathrm{O}), 207.5(C=\mathrm{N}), 197.3(\mathrm{Fe}-C=\mathrm{CH}), 163.7\left(\mathrm{Fe}-C \mathrm{C}_{6} \mathrm{H}_{3} \mathrm{CF}_{3}\right), 146.8\left(C\right.$-ipso $\left.\mathrm{C}_{6} \mathrm{H}_{3} \mathrm{CF}_{3}\right), 143.1(C \mathrm{H}$ o- $\left.\mathrm{C}_{6} \mathrm{H}_{3} \mathrm{CF}_{3}\right), 139.6(=C H), 139.8$ (C-ipso Tol), $137.3\left(C\right.$-Me Tol), 132.9-118.9 $\left(C \mathrm{H}\right.$ arom $+C \mathrm{~F}_{3}+$ $\left.C-\mathrm{CF}_{3}\right), 84.0,82.9(\mathrm{Cp}), 50.1,42.8(\mathrm{NMe}), 21.6\left(\mathrm{MeC}_{6} \mathrm{H}_{4}\right) .{ }^{19} \mathrm{~F} \mathrm{NMR}\left(\mathrm{CDCl}_{3}, 293 \mathrm{~K}\right): \delta$-62.70.

\subsection{X-ray structural determinations.}

Compounds $3 \mathbf{b}, \mathbf{3 c} \cdot \mathbf{0 . 5} \mathbf{C}_{5} \mathbf{H}_{12}, 3 \mathbf{e}$ and $\mathbf{3 g} \cdot \mathbf{C}_{5} \mathbf{H}_{12}$ were crystallised from $\mathrm{CH}_{2} \mathrm{Cl}_{2} /$ pentane at $20{ }^{\circ} \mathrm{C}$. Crystal data and collection details are reported in Table 3. The diffraction experiments were carried out on a Bruker SMART 2000 diffractometer equipped with a CCD detector using Mo-K $\alpha$ radiation. Data were corrected for Lorentz polarization and absorption effects (empirical absorption correction SADABS) [20]. Structures were solved by direct methods and refined by full-matrix least-squares based on all data using $F^{2}$ [21]. Hydrogen atoms were fixed at calculated positions and refined by a riding model. All non-hydrogen atoms were refined with anisotropic displacement parameters, unless otherwise stated. The $\mathrm{Cp}$ ligands bound to $\mathrm{Fe}(1), \mathrm{Fe}(2)$ and $\mathrm{Fe}(3)$ in $\mathbf{3} \mathbf{c} \cdot \mathbf{0 . 5} \mathbf{C}_{\mathbf{5}} \mathbf{H}_{\mathbf{1 2}}$ and the $\mathrm{CF}_{3}$ group in $\mathbf{3 g} \cdot \mathbf{C}_{\mathbf{5}} \mathbf{H}_{12}$ are disordered over two positions, whereas the $\mathrm{C}_{5} \mathrm{H}_{12}$ molecule in $\mathbf{3 g} \cdot \mathbf{C}_{5} \mathbf{H}_{12}$ is disordered over four positions. Disordered atomic positions were split and refined isotropically using similar distance and similar $U$ restraints and one occupancy parameter per disordered group. In the case of the $\mathrm{C}_{5} \mathrm{H}_{12}$ molecule in $\mathbf{3 g} \cdot \mathbf{C}_{\mathbf{5}} \mathbf{H}_{\mathbf{1 2}}$ the sum of the occupancy parameters for the four positions was restrained to unit. Two independent molecules are present in the asymmetric unit of $\mathbf{3 c} \cdot \mathbf{0 . 5} \mathbf{C}_{\mathbf{5}} \mathbf{H}_{\mathbf{1 2}}$. 
Table 3

Crystal data and experimental details for $\mathbf{3 b}, \mathbf{3 c} \cdot \mathbf{0 . 5 \mathbf { C } _ { 5 }} \mathbf{H}_{\mathbf{1 2}}, \mathbf{3 e}$ and $\mathbf{3 g} \cdot \mathbf{C}_{\mathbf{5}} \mathbf{H}_{\mathbf{1 2}}$.

\begin{tabular}{|c|c|c|c|c|}
\hline Complex & $\mathbf{3 b}$ & $3 c \cdot 0.5 C_{5} H_{12}$ & $3 e$ & $3 \mathrm{~g} \cdot \mathrm{C}_{5} \mathrm{H}_{12}$ \\
\hline Formula & $\mathrm{C}_{38} \mathrm{H}_{33} \mathrm{BrFe}_{2} \mathrm{~N}_{2} \mathrm{O}_{2}$ & $\mathrm{C}_{41.5} \mathrm{H}_{42} \mathrm{Fe}_{2} \mathrm{~N}_{2} \mathrm{O}_{3}$ & $\mathrm{C}_{39} \mathrm{H}_{33} \mathrm{~F}_{3} \mathrm{Fe}_{2} \mathrm{~N}_{2} \mathrm{O}_{2}$ & $\mathrm{C}_{37} \mathrm{H}_{39} \mathrm{~F}_{3} \mathrm{Fe}_{2} \mathrm{~N}_{2} \mathrm{O}_{2}$ \\
\hline $\mathrm{F} w$ & 741.27 & 728.47 & 730.37 & 712.40 \\
\hline$T, \mathrm{~K}$ & 293(2) & 293(2) & $150(2)$ & 293(2) \\
\hline$\lambda, \AA$ & 0.71073 & 0.71073 & 0.71073 & 0.71073 \\
\hline Crystal system & Monoclinic & Triclinic & Monoclinic & Monoclinic \\
\hline Space group & $P 2_{1} / n$ & $P \overline{1}$ & $P 2_{1} / n$ & $C 2 / c$ \\
\hline$a, \AA$ & $14.411(3)$ & $9.988(2)$ & $14.397(3)$ & $33.456(7)$ \\
\hline$b, \AA$ & $16.116(3)$ & $17.106(3)$ & $16.236(3)$ & $12.717(3)$ \\
\hline$c, \AA$ & $15.460(3)$ & $22.806(5)$ & $15.189(3)$ & $22.746(5)$ \\
\hline$\alpha,^{\circ}$ & 90 & $71.26(3)$ & 90 & 90 \\
\hline$\beta,^{\circ}$ & $114.53(3)$ & $88.67(3)$ & $114.50(3)$ & $131.16(3)$ \\
\hline$\gamma,^{\circ}$ & 90 & $79.19(3)$ & 90 & 90 \\
\hline Cell volume, $\AA^{3}$ & $3266.5(11)$ & $3621.6(13)$ & $3230.7(11)$ & $7286(3)$ \\
\hline$Z$ & 4 & 4 & 4 & 8 \\
\hline$D_{\mathrm{c}}, \mathrm{g} \mathrm{cm}^{-3}$ & 1.507 & 1.336 & 1.502 & 1.299 \\
\hline$\mu, \mathrm{mm}^{-1}$ & 2.148 & 0.842 & 0.954 & 0.844 \\
\hline$F(000)$ & 1512 & 1524 & 1504 & 2960 \\
\hline Crystal size, $\mathrm{mm}$ & $0.19 \times 0.16 \times 0.11$ & $0.24 \times 0.21 \times 0.13$ & $0.36 \times 0.26 \times 0.19$ & $0.21 \times 0.15 \times 0.12$ \\
\hline$\theta$ limits, $^{\circ}$ & $1.63-25.03$ & $0.94-25.03$ & $1.64-25.68$ & $1.62-25.02$ \\
\hline Reflections collected & 28607 & 28638 & 29661 & 31663 \\
\hline \multirow{2}{*}{ Independent reflections } & $5773\left(R_{\mathrm{int}}=\right.$ & $12784\left(R_{\mathrm{int}}=\right.$ & $6134\left(R_{\mathrm{int}}=\right.$ & $6431\left(R_{\mathrm{int}}=\right.$ \\
\hline & $0.1301)$ & 0.0809) & $0.0520)$ & $0.0991)$ \\
\hline Data/restraints/parameters & $5773 / 0 / 410$ & $\begin{array}{c}12784 / 477 / \\
847\end{array}$ & $6134 / 0 / 437$ & $6431 / 371 / 455$ \\
\hline Goodness on fit on $F^{2}$ & 0.911 & 0.917 & 1.033 & 1.065 \\
\hline$R 1[I>2 \sigma(I)]$ & 0.0658 & 0.0660 & 0.0355 & 0.0773 \\
\hline$w R 2$ (all data) & 0.1887 & 0.1947 & 0.0799 & 0.2412 \\
\hline $\begin{array}{c}\text { Largest diff. peak and } \\
\text { hole, e. } \AA^{-3}\end{array}$ & $0.453 /-0.901$ & $0.683 /-0.399$ & $0.538 /-0.847$ & $0.879 /-0.877$ \\
\hline
\end{tabular}




\section{Supplementary material}

Crystallographic data for the structural analyses have been deposited with the Cambridge Crystallographic Data Centre, CCDC Nos. 251913 for $\mathbf{3 b}, 251914$ for $\mathbf{3 c} \cdot \mathbf{0 . 5 C _ { \mathbf { 5 } }} \mathbf{H}_{\mathbf{1 2}}, 251915$ for $\mathbf{3 e}$ and 251916 for $\mathbf{3 g} \cdot \mathbf{C}_{\mathbf{5}} \mathbf{H}_{\mathbf{1 2}}$. Copies of this information can be obtained free of charge from the Director, CCDC, 12 Union Road, Cambridge, CB2 1EZ, UK (Fax: +44-1233-336033; e-mail: deposit@ccdc.cam.ac.uk or http://www.ccdc.cam.ac.uk).

\section{References}

[1] (a) V. Yu. Kukushkin, A. J. L. Pombeiro, Chem. Rev. 102 (2002) 1771; (b) R. A. Michelin, M. Mozzon, R. Bertani, Coord. Chem. Rev. 147 (1996) 299; (c) F. F. Fleming, Q. Wang, Chem. Rev. 103 (2003) 2035.

[2] (a) S.I. Murahashi, T. Naota, H. Taki, M. Mizuno, H. Takaya, S. Komiya, Y. Mizuho, N. Oyasato, M. Hiraoka, M. Hirano, A. Fukuoka, J. Am. Chem. Soc. 117 (1995) 12436; (b) B. M. Trost, F. D. Toste, A. B. Pinkerton, Chem. Rev. 101 (2001) 2067.

[3] (a) S. I. Murahasci, H. Takaya, Acc. Chem. Res. 33 (2000) 225; (b) D. P. Fairlie, W. G. Jackson, B. W. Skeleton, H. Wen, A. H. White, W. A. Wickramasinghe, T. C. Woon, H. Taube, Inorg. Chem. 36 (1997) 1020; (c) R. W. Hay, F. M. McLaren, Transition Met. Chem. 24 (1999) 398.

[4] (a) L. Maresca, G. Natile, F. P. Intini, F. Gasparrini, A. Tiripicchio, M. Tiripicchio-Camellini, J. Am. Chem. Soc. 108 (1986) 1180; (b) A. Syamala, A. R. Chakravarty, Inorg. Chem. 30 (1991) 4699; (c) S. G. Feng, P. S. White, J. L. Templeton, Organometallics 12 (1993) 1765; (d) S. G. Feng, P. S. White, J. L. Templeton, Organometallics 113 (1994) 1214; (e) R. A. Michelin, M. Mozzon, R. Bertani, F. Benetollo, G. Bombieri, R. J. Angelici, Inorg. Chim. Acta 222 (1994) 327; (f) U. Belluco, F. Benetollo, R. Bertani, G. Bombieri, R. A. Michelin, M. Mozzon, O. Tonon, J. L. Pombeiro, F. C. G. da Silva, Inorg. Chim Acta 334 (2002) 437.

[5] (a) F .P. Fanizzi., F. P. Intini, G. Natile, J. Chem. Soc., Dalton Trans. (1989) 947; (b) J. M. Casas, M. H. Chisoholm, M. V. Sicilia, W. E. Streib, Polyhedron 10 (1991) 1573; (c) R. Cini, P. A. Caputo, F. P. Intini, G. Natile. Inorg. Chem. 34 (1995) 1130; (d) C. S.Chin, D. Chong, B. Lee, H. Jeong, G. Won, Y. Do, Y. J. Park, Organometallics 19 (2000) 638.

[6] (a) T. Yoshida, T. Matsuda, T. Okano, T. Kitani, S. Otsuda,. J. Am. Chem. Soc. 101 (1979) 2027; (b) C. M. Jensen and W. C. Trogler, J. Am. Chem. Soc. 108 (1986) 723; (c) T. C. Woon, D. P. Fairlie, Inorg. Chem. 31 (1992) 4069; (d) K. J. Nelson, R. W. McGraff, D. R. Powell, Inorg. Chim. Acta 304 (2000) 130. 
[7] (a) S. G. Feng, J. L. Templeton, Organometallics 11 (1992) 1295; (b) W. Y. Yeh, C. S. Ting. S. M. Peng, G. H. Lee Organometallics 14 (1995) 1417; (c) M. E. Cucciolito, V. De Felice, F. Giordano, I. Orabona, F. Ruffo, Eur. J. Inorg. Chem. (2001) 3095.

[8] (a) V. G. Albano, L. Busetto, M. Monari, V. Zanotti, J. Organomet. Chem. 606 (2000) 163;

(b) L. Busetto, F. Marchetti, S. Zacchini, V. Zanotti, Eur. J. Inorg. Chem. (2004) 1494; (c) L. Busetto, F. Marchetti, S. Zacchini, V. Zanotti, J. Braz. Chem. Soc. 6 (2003) 902; (d) L. Busetto, F. Marchetti, S. Zacchini, V. Zanotti, E. Zoli, J. Organomet. Chem. in press.

[9] V. G. Albano, L. Busetto, F. Marchetti, M. Monari, V. Zanotti, J. Organomet. Chem. 649 (2002) 64.

[10] V. G. Albano, S. Bordoni, L. Busetto, F. Marchetti, M. Monari, V. Zanotti, J. Organomet. Chem. 684 (2003) 37.

[11] W. Parshall, Acc. Chem. Res. 3 (1970) 139.

[12] (a) J. Dupont, M. Pfeffer, J. Spencer, Eur. J. Inorg. Chem. (2001) 1917; (b) A. W. Kleij, R. J. M. K. Gebbink, P. A. J. van den Nieuwenhuijzen, H. Kooijman, M. Lutz, A. L. Spek, G. Van Koten, Organometallics 20 (2001) 171; (c) A. Sundermann, O. Uzman, J. M. L. Martin, Chem. Eur. J. 7 (2001) 1703.

[13] (a) F. Neve, A. Crispini, S. Serroni, F. Loiseau, S. Campagna, Inorg. Chem. 40 (2001) 1093;

(b) B. B. Eran, D. Singer, K. Praefcke, Eur. J. Inorg. Chem. (2001) 111.

[14] (a) M. B. Dinger, W. Henderson, J. Organomet. Chem. 557 (1998) 231; (b) P. A. Bonnardel, R. V. Parish, R. G. Pritchard, J. Chem. Soc., Dalton Trans. (1996) 3185; (c) R. V. Parish, B. P. Howe, J. P. Wright, J. Mack, R. G. Pritchard, R. G. Buckley, A. M. Elsome, S. P. Fricjer, Inorg. Chem. 35 (1996) 1659.

[15] (a) V. G. Albano, L. Busetto, C. Camiletti, C. Castellari, M. Monari, V. Zanotti, J. Chem. Soc., Dalton Trans. (1997) 4671; (b) V. G. Albano, L. Busetto, F. Marchetti, M. Monari, S. Zacchini, V. Zanotti, Organometallics 22 (2003) 1326; c) V. G. Albano, L. Busetto, F. Marchetti, M. Monari, S. Zacchini, V. Zanotti, J. Organomet Chem. 689 (2004) 528; (d) V. G. Albano, L. Busetto, F. Marchetti, M. Monari, S. Zacchini, V. Zanotti, Organometallics 23 (2004) 3348.

[16] L. Busetto, C. Camiletti, V. Zanotti, V.G. Albano, P. Sabatino, J. Organomet. Chem. 593594 (2000) 335.

[17] Wilker, D. Leibfritz, R. Kerssebaum, W. Beimel, Magn. Reson. Chem. 31 (1993) 287.

[18] Stott, J. Stonehouse, J. Keeler, T. L. Hwang, A. J. Shaka, J. Am. Chem. Soc. 117 (1995) 4199. 
[19] (a) G. Cox, C. Dowling, A. R. Manning, P. McArdle, D. Cunnigham, J. Organomet. Chem. 438 (1992) 143; (b) K. Boss, C. Dowling, A. R. Manning, J. Organomet. Chem. 509 (1996) 19.

[20] M. Sheldrick, SADABS, Program for Empirical Absorption Correction, University of Göttingen, Germany, 1996.

[21] G. M. Sheldrick, SHELX97-Program for the refinement of Crystal Structure, University of Göttingen, Germany, 1997. 
Graphical contents entry

\section{Nitrile ligands activation in dinuclear aminocarbyne complexes}

Luigi Busetto, Fabio Marchetti, Stefano Zacchini, Valerio Zanotti * and Eleonora Zoli

Dipartimento di Chimica Fisica ed Inorganica, Università di Bologna, Viale Risorgimento 4, I40136 Bologna, Italy

The diiron aminocarbyne complexes 2 , containing aryl nitrile ligands $\left(p-\mathrm{NCC}_{6} \mathrm{H}_{3} \mathrm{R}^{\prime}, \mathrm{R}^{\prime}=\mathrm{H}\right.$, $\mathrm{Br}, \mathrm{Ph}, \mathrm{OMe}, \mathrm{COOMe}, \mathrm{CF}_{3}$ ) react with TolCCLi affording the corresponding complexes $\mathbf{3}$. The reaction involves attack of the acetylide to the coordinated nitrile, $\mathrm{C}-\mathrm{N}$ coupling with the bridging aminocarbyne together with orthometallation of the $p$-substituted aromatic ring and breaking of the Fe-Fe bond.

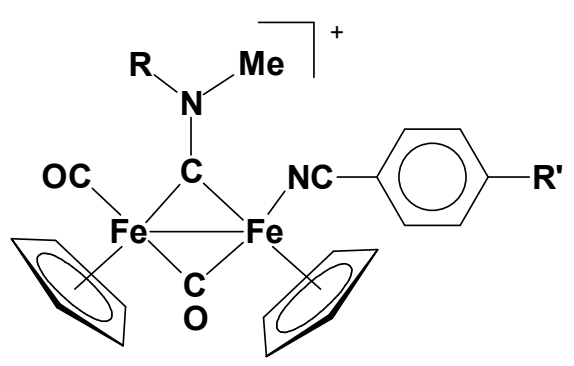

2

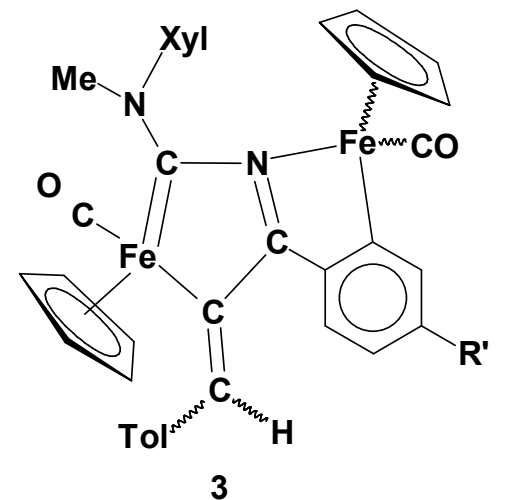

3 